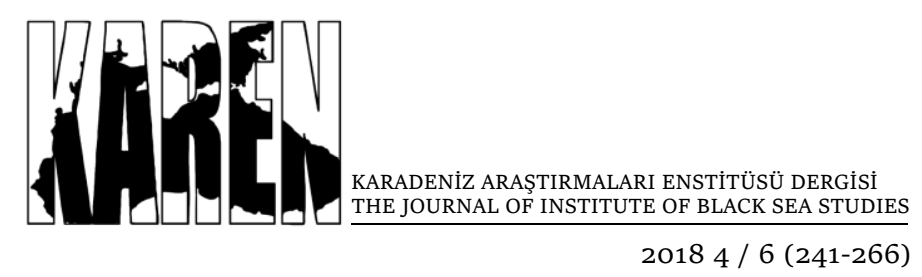

Çiğdem, Süleyman-Emir, Osman-İlhan, Hüseyin, "Yüzey Araştırmaları Işığında MÖ II. Yüzyıldan MS 10. Yüzyılın Başlarına Kadar Bayburt ve Çevresi”, Karadeniz Araştırmaları Enstitüsü Dergisi, 4/6, ss.241-266.

* Araştırma makalesidir.

${ }^{* *}$ Prof. Dr. Atatürk Üniversitesi, Edebiyat Fakültesi, Tarihi Bölümü, E-Posta: scigdem@atauni.edu.tr. ORCID: 0000-0003-0076-7052

${ }^{* * *}$ Dr. Öğr. Üyesi Karadeniz Teknik Üniversitesi, Edebiyat Fakültesi, Tarih Bölümü,

E-Posta:osmanemir1461@gmail.com ORCID: 0000-0002-7965-3869

${ }^{* * * *}$ Arş. Gör., Bayburt Üniversitesi, İnsan ve Toplum Bilimleri Fakültesi, Tarih Bölümü,

E-Posta:huseyinilhan@bayburt.edu.tr ORCID: 0000-0003-0232-4482

Anahtar Kelimeler: Bayburt, Roma, Mithradates, Haldia, Doğu Roma

Keywords: Bayburt, Rome, Mithradates, Haldia, East Rome

\section{YÜZEY ARAŞTIRMALARI IŞIĞINDA MÖ II. YÜZYILDAN MS 10. YÜZYILIN BAŞLARINA KADAR BAYBURT VE ÇEVRESI ${ }^{*}$}

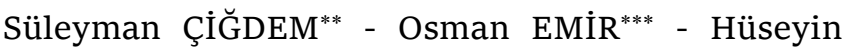
ILHAN $^{* * * *}$

Öz: Kuzeydoğu Anadolu Bölgesi'nin önemli kentlerinden biri olan Bayburt, Geç Hellenistik dönemden itibaren güçler çatışmasının merkezinde yer almıştır. Roma'nın doğudaki sınır savunmasının önemli bir parçası olan bu kent, önce Roma - Parth ardında da Doğu Roma - Sasani mücadelelerinde stratejik olarak önemli görevler üstlenmiştir.

Bu çalışmada yazılı ve arkeolojik veriler ışı̆̆ında Geç Hellenistik dönemden Roma İmparatorluğu'nun sonuna kadar Bayburt ve çevresinde yaşanan askerî ve siyasi gelişmeler; bu gelişmeler sürecinde Bayburt ve çevresinin stratejik konumu ele alınacaktır.

\section{BAYBURT AND ITS SURROUNDINGS FROM $2^{\text {nd }}$ CENTURY BC UNTIL THE BEGINNING OF $10^{\text {th }}$ CENTURY IN THE LIGHT OF SURFACE SURVEYS}

Abstract: Bayburt, one of the most important cities of Northeastern Anatolia, has been at the centre of the clash of powers since the late Hellenistic period. The city, which was an important part of the defence of the eastern front of the empire, was strategically very important for the Roman and Iranian wars.

In this study, military and political developments in Bayburt and its surroundings from the Late Hellenistic period until the end of the Roman Empire will be discussed in the light of written and archaeological data. 


\section{Giriş}

İtalya'da büyük bir askerî güç olarak tarih sahnesine çıkan Roma İmparatorluğu, Seleukos Krallığının Anadolu'daki yayılımının kendisi için büyük bir tehlike olacağını fark etti, Yunanistan'ın bazı şehirlerinde Roma karşıtı hareketler başlayınca ve bu şehirler Seleukos kralını başlarına geçmesi için davet edince, III. Antiokhos ordusuyla Yunanistan'a geçti. ${ }^{1} \mathrm{Bu}$ gelişme üzerine Atina, Bergama ve Rodos kuvvetlerini de yanına alan Roma, Antiokhos'u geri çekilmek zorunda biraktı. Ancak Romalılar kralın peşini bırakmadılar; Çanakkale Boğazı'nı geçerek ilk defa Anadolu topraklarına girip komutan L. Cornelius Scipio ile abisinin idare ettiği 30.000 bin kişilik ordu ile Antiokhos'u Magnesia/Manisa yöresinde yenilgiye uğrattılar. ${ }^{2}$ Böylece MÖ 190 yllından itibaren Anadolu'da baş aktörlüğünü Roma'nın yaptığı yeni bir güç dengesi kurulmaya başlandı. Roma İmparatorluğu Küçük Asya'da önceleri toprak almayı tercih etmemiş, kazanılan toprakları, savaşlar sırasında kendisine yardım eden müttefikleri arasında pay ederek bir denge siyaseti kurmuştur. ${ }^{3}$ Böylelikle Roma, Anadolu kentleri ile önceleri yaptığı dostluk anlaşmalarını, sonradan doğuda hâkimiyeti ele geçirme düşüncesi ile ittifak anlaşmalarına dönüştürmüştür.

MÖ 129 yillarında Toroslara kadar hemen hemen bütün Anadolu bir şekilde Roma İmpratorluğu'na bağlanmış olmakla beraber, Pontos krallarıyla uzun yıllar sürecek olan Pontos-Roma mücadelesi de bu tarihlerden itibaren başlamıştır. Pontos'un son büyük kralı VI. Mithradates ve komutanları Karadeniz kıyı bölgesini kolaylıkla ele ge- çirmiş, ${ }^{4}$ Kuban-Kolhis bölgesini kontrol altına almış, egemenliğini doğuya doğru genişletmiştir (MÖ 114). ${ }^{5}$ Daha sonra Paphlagonia kralı III. Nikomedes ile anlaşarak Paphlagonia ve Galatia'yı paylaşmışlardır (MÖ 104). Ancak her iki kral, Kappadokia üzerine anlaşamayarak kendi aralarında savaşa girmişlerdir. ${ }^{6}$

MÖ 95 yılında Armenia kralı II. Tigranes (MÖ 95-55), uzun süre Parth kralı II. Mithradates'in (MÖ 123/2-90) yanında rehin olarak kaldıktan sonra babasının ölümü üzerine Armenia tahtına oturdu ve bir müddet sonra da VI. Mithradates ile hem dostluk hem de akrabalık kurdu. Böylelikle VI. Mithradates Anadolu'da büyük bir güç olan Parth İmparatorluğu ve Armenia Krallığı'nın desteğini aldı. ${ }^{7}$ Bir süre sonra da kral, II. Tigranes ile anlaşarak MÖ 95'te yeniden Kappadokia'yı işgal etti. ${ }^{8}$ Ancak Aquilius komutasında bir Roma ordusunun kendisine karşı hazırlık yaptığını öğrenen kral, işgal ettiği Kappadokia ve Bithynia topraklarından çekilse de şöhret peşinde olan Aquilius'un savaşmak konusunda israr etmesi iki güçü karşı karşıya getirdi. ${ }^{9}$ IV. Mithradates Romalılar ile yapılan ilk savaştan zaferle ayrıldı ve devan eden günlerde Anadolu'daki Roma askerî güçleri yarımadayı terketmek zorunda kaldılar. ${ }^{10}$ Mithradates'in tekrar Anadolu'da hâkim olmasına en çok Romalı vergi mültezimleri tarafından soyulan halk memnun olmuş, Anadolu halkı ona "Asya'nın Kurtarıcısı" ve "Yeni Dionysos" gibi lakaplar vermiştir. ${ }^{11}$

Roma, kendi sınırları içerisinde yaşadığı iç savaşlar dolayısıyla ilk zamanlar VI. Mithradates'in bu askerî başarılarına tepki gösteremedi, ancak Müttefikler Savaşı'ndan

\footnotetext{
${ }^{1}$ Errington, 1972: 170; 1989: $271 \mathrm{vd.}$

${ }^{2}$ Liv. XXXVII. 47-7; Tacit. Ann. III, 62; Eut. IV. 4; ayrica bk. Payne, 1970: 110; Errington, 1989: 282-287.

3 Polyb. XXI. 45. 7-10; Liv. XXXVIII. 39. 13; ayrıca bk. Jones, 1969: 51-54.

${ }_{4}$ Mommsen, 1958, dpnt. 153; Hind, 1992: 139-140; Saprykin, 2003: $3 \mathrm{vd}$.

${ }^{5}$ Strab. I. 2. 1; VII. 2. 17; VII. 6. 3; ayrica bk. Olbrycht, 2011: 275-276; Molev, 1995: 40-41; 2009, 321: Mayor, 2013: 133; Emir, 2014: $81 \mathrm{vd}$.
}

\footnotetext{
${ }^{6}$ Iust. XXXVIII. 1. 10; Memnon. 30. 1; ayrica bk. Rostovtzeff -Ormerod, 1932: 234-236; Arslan, 2007: 99; Ballesteros-Pastor, 2008: 54; Madsen, 2009a: 195.

${ }^{7}$ Manandyan, 2007: $20 \mathrm{vd.}$

${ }^{8}$ Iust. XXXVIII. 2. 8; ayrica bk. Olbrycht, 2009: 172.

9 App. Mithr. 57; Cass. Dio XXXI. 99. 2; ayrica bk. Sherwin-White, 1984: 112; Dmitriev, 2006: 293 vd.

${ }^{10}$ Memnon 31. 3; App. Mithr. 11-19; Liv. perioch 76; Eutr. V. 5; ayrica bk. Hind, 1992: 148-149; Arslan, 2007: 144

${ }^{11}$ Hind 1992, 149; Arslan, 2007, 145.
} 
sonra dikkatini Anadolu'ya çevirdi. Mithradates uzun bir süre Roma'ya karşı başarılar elde etti. ${ }^{12}$ Ancak Kral daha sonra Roma ordusu ile girdiği savaştan mağlup çıkınca ve Küçük Asya'da birçok kent onun aleyhine dönünce Roma ile anlaşma imzalayarak geri çekildi ve böylelikle Birinci Mithradates Savaşları sona erdi (MÖ 88-85). ${ }^{13}$

Birinci Mithradates Savaşları'ndan Roma başarılı bir şekilde çıkmasına ve lehine bir anlaşma yapmasına rağmen Pontos Krallığ 1 ve VI. Mithradates'in Anadolu'daki varlığ 1 Roma için ciddi bir tehdit olmaya devam ediyordu. Bu yüzden Roma senatosu tarafından Anadolu'da savaşacak kara ordularının komutanlığına getirilen Licinius Lucullus, ${ }^{14}$ Mithradates tehlikesini tamamen ortadan kaldırmak istiyordu. ${ }^{15}$ Lucullus bu amaçla hazırladığı bir ordu ile Pontos Krallığ 1 topraklarına doğru ilerlemeye başladı. Bunun üzerine Mithradates, özellikle Karadeniz havzasında yaşayan halklardan topladığ $\breve{1}$ askerleri ile Lucullus'u Kabeira/ Niksar'da beklemiş, Romalıların gelmekte olduğunu öğrenince Lykos/Kelkit Çayı'nı kadar geri çekilmiş ve burada Lucullus'u yenilgiye uğratmıştır (MÖ71). ${ }^{16}$ Fakat Lucullus aldığ men Mithradates'in peşini bırakmadığ 1 gibi, Mithradates'in askerleri de isyan ç1karıp kralın yakınlarını öldürdüler. Mithradates bu arada damadı Tigranes/Dikran'ın ülkesine kaçmayı başardı. ${ }^{17}$ Lucullus yaptığı seferlerle Erivan'ın güneyine kadar ilerlemişse de Pontos Krallığı'nın sonunu getirememiştir. ${ }^{18}$

Yukarıda anlatılan gelişmelere paralel olarak Roma-Mithradates Savaşları ve bu savaşların Pontos Bölgesi'ne taşınması ile

\footnotetext{
${ }^{12}$ Roma-Pontos savaşlarında her iki taraf da Heraklia/Karadeniz Ereğlisi'nin güçlü donanmasından yararlanmaya çalışmışlardır. Akkaya, 1994: 18.

${ }^{13}$ Mommsen, 1958: 136-137, 173; Arslan, 2007: 127 vd.

${ }^{14}$ Memnon 37. 1; Plut. Luc. V. 1; 6. 1-4; ayrica bk. Arslan, 2007: 307-308.

${ }^{15}$ Eut. VI - VII. 6.

${ }^{16}$ Rosovtzeff-Ormerod, 1971: 258-259; Ormerod-Cary, 1971: 360-371; Ball 2002: 11; Lucullus'un Lykos/Kelkit Vadisi'ndaki operasyonları için bk. Ormerod, 1971: 897-898.
}

Bayburt'un da içinde bulunduğu Kuzeydoğu Anadolu Bölgesi askerî ve siyasi faaliyetlerinin merkezi hâline gelmişti.

\section{Roma Cumhuriyet Dönemi'nde Bay- burt ve Çevresi}

MÖ 120 yılında Pontos Krallığı'nın başına geçen Mithradates VI Eupator ile Kuzeydoğu Anadolu toprakarı başta olmak üzere Anadolu yeni bir siyasi çatışmanın içine süreklendi. Bir tarafta asil Pers soyundan gelen ve Anadolu'dan tüm Roma varlığını uzaklaştırmak isteyen VI. Mithradates ile diğer yanda bölgedeki kazanımlarını kaybetmek istemeyen Roma arasında yaklaşık 30 yll süren büyük bir mücadele başladı. Ancak bu mücadelenin sonlarına doğru VI. Mithradates'in Roma'ya karşı olan direnci kırıldı ve Kral Roma consul'ü Lucullus'un ordusuna mağlup olarak krallığın asıl merkezine, Kuzeydoğu Anadolu topraklarına geri çekilmek zorunda kadı. Bununla birlikte bu dönemde Lucullus'un Pontos'u ele geçirip tamamen ortadan kaldıramaması nedeniyle ${ }^{19}$ Pontos Krallığı'nı ortadan kaldırma görevi bu sefer Pompeius Magnus'a ${ }^{20}$ verildi (MÖ 67). ${ }^{21}$ Burada hemen şunu belirtmeliyiz ki bu dönemde gelişen olaylar esnasında, önemli geçiş noktası üzerinde bulunan, Satala ile beraber Gümüşhane'nin güney bölgesi (Kelkit-Şiran) ile Bayburt ve çevresi bu savaşlarda, düşman güçlerin bağlantı noktalarından biri olmuştur. ${ }^{22}$ Büyük bir olasılıkla Mithradates'in düşmanı karşılamak için takip ettiği güzergâh, Satala üzerinden gerçekleştirilmiştir. ${ }^{23}$ Mithradates, Pomepius'a karş1 Kabeira'da aldığ 1 yenilgiden sonra Kelkit havzasına kadar çekilmiş, Dasteria yakınlarında stratejik bir mevkide bulunan sulak

\footnotetext{
${ }^{17}$ Arslan, 2007: 362.

${ }^{18}$ Eut. V. 9; Lloyd, 1997: 206 vd.; Arslan, 2007: 415416.

${ }^{19}$ Arslan 2007: 432-433

${ }^{20}$ Roma'nın doğrudan Kappadokia'nın doğu ve güneydoğusuna doğru ilerlemesi Pompeius'la başlamıştır. Isaac, 1990: 14 .

${ }^{21}$ Plut. Luc. XXXIII vd.; Pomp. XXX. 1-3; Cic. Leg. Man. IX. 26; X. 27-28; App. Mithr. 97; ayrıca bk. Hilman 1993: 212 vd.

${ }^{22}$ Anderson, 1922: 105.

${ }^{23}$ Anderson, 1922: 105.
} 
bir dağ mişti. ${ }^{24}$ Pompeius Mithradates'in ordusunu Lykos/Kelkit Irmağı'nın kenarında yendi, Mithradates Akampsis/Çoruh Irmağı'nı geçerek Kolkhis'e çekildi. ${ }^{25} \mathrm{Bu}$ geri çekilme sırasında Mithradates, kralî hazinelerin saklı olduğu Sinoria ${ }^{26}$ (Bayburt) Kalesi'ne ulaşmış, burada kendisini takip eden komutan ve askerlerini ödüllendirmiştir. ${ }^{27}$

Strabon ${ }^{28}$ Sinoria olarak adlandırdığ 1 Bayburt Kalesi'nin stratejik konumunu ve burada geçen olayları şu şekilde tanımlamaktadir:

Sinoria (Bayburt Kalesi), Büyük Armenia sınırlarına yakındı. Bu nedenle Theophanes imlasını Synoria olarak değiştirmiştir. Bölgede genel olarak Paryadros Dağ silsileleri arasında iyi sulanmış ve ormanlık yerlerin bulunuşu ve birçok yerlerin derin vadiler ve dik uçurumlarala kaplı oluşu, böyle kaleler yapmaya çok elverişlidir. Bu nedenlerden (Mithradates) hazinelerinin çoğunu yerleştirdiği kaleleri burada yaptırmıştır ve sonuçta gerçekten Pompeius ülkeyi istila ettiği zaman, Mithradates Pontus Krallığı'nın bu en uç kısımlarına kaçmış ve Akilisene'de (yakınında Akilisene'yi Küçük Armenia'dan ayıran Euphrates vardır) Dasteira, yakınında sulak bir dağı ele geçirmiş ve kuşatılınca dağları aşarak Kolkhis'e ve oradan Bosporus'a kaçmaya zorlanıncaya kadar burada kalmıştır. Bu yerin yakınında Küçük Armenia'da Pompeius, Nikopolis adında bir kent kurmuştur. Burası bugüne kadar kalmıştır ve oldukça kalabalıktır.

Mithradates'in geçici olarak kullandığı Bayburt Kalesi'nde yapılan yüzey araştırmalarında kalenin ilk Tunç Çağı'na kadar

${ }^{24}$ Strab. XII. 3. 28; Plut. Pomp. XXXII. 2; App. Mithr. 99.

${ }^{25}$ Strab. XI. 2. 13; App. Mithr. 101; ayrica Chahin, 1987: 234-235; Sherwin-White, 2008: 253-254; Van Wijlick, 2013: 37.

${ }^{26}$ Bu kale Plutarkhos (Pomp. XXXII. 8)'ta Sinora, Appianos (Mithr. 101)'ta Simoreks, Ammianus Marcellinus (XVI. 7. 10)'ta ise Sinhorium/Synorium olarak adlandırılmaktadır.

${ }_{27}$ Plut. Pomp. XXXII. 8; App. Mithr. 101; ayrica bk. Sherwin-White, 2008: 252.

${ }^{28}$ Strab. XII, III, 31. Çiğdem-Emir, 2017: 28.

${ }^{29}$ Sagona, 1990: 426.

${ }^{30}$ Çiğdem-Özkan-Yurttaş, 2014: 71-72.

${ }^{31}$ Strab. XII, 3. 13; Eut. V. 20; Jones 1969, 157. gittiği belirtilmiştir. ${ }^{29}$ Bununla birlikte 2013 yılında ekibimiz tarafından bölgede gerçekleştirilen yüzey araştırmalarında Bayburt kale duvarlarının en alt kısmını Hellenistik ve Roma dönemlerine tarihlendirmenin mümkün olduğu görülmüştür. Zira yüzeyde de Roma dönemi keramiğiyle de karşılaşılmıştır. ${ }^{30}$

Mithradates Bayburt Kalesi'ne büyük bir olasılıkla Kelkit, Köse ve Demirözü üzerinden ulaşmış olmalıdır. Zira Kabeira'dan (yani bugün Niksar'dan itibaren) Mithradates'in önce Dasteira'ya (yani bugün Sivas ile Erzincan arasinda bir yer), oradan da Sinoria’ya geldiğini görmekteyiz. (Harita 1). Bu antik yol güzergâhı incelendğinde Dasteira ile Sinoria arasında gelecekte Roman'nın doğudaki en önemli garznizonun kurulucacağı Satala'nın olduğu Sadak köyü yer almaktadır. Bu aynı zamanda özellikle Roma döneminde işlek kullanılan ve batıdan doğuya giden antik yol güzergâhını da temsil etmektedir. Bundan sonra Pompeius, Doğu Karadeniz kıyısını takip ederek Kırım'a ulaştı. Strabon ve Eutropius, Pompeius'un Pharnakia/Pontos bölgesini, Kolhis, Armenia Minor ve Trapezusia/Trapezos'u savaşlarda gösterdiği başarılardan dolayı Galatialı Deiotaros'a verdiğini ifade etmektedirler. ${ }^{31}$ Böylece Bayburt ve çevresi Deiotaros'a bağlanmış olmalıdır. ${ }^{32}$

Deiotaros'un krallı̆̆ı, diğer Galat tetrarkhes'leri ve güneyde Kommagene Krallığı, ileride muhtemel tehlike olarak görülen

\footnotetext{
${ }^{32}$ Magie, 1950: 1237, dn. 41; Sherk, 1980: 975; Jones, 1998: 158; Arslan, 2000: 149-150; Kaya, 2005a: 131132. Deiotaros, kraliyet topraklarına ait stratejik noktalarda güçlü kaleler yaptırdı. Kaynaklarda geçen bu kalelerden en önemlileri, bugün Bayburt sınırları içerisinde olduğu düşünülen Sintoion ve Sinoria kaleleridir. Sinoria ismi, Deiotaros'un babası Sinorix ile ilişkili olabilir. Bk. Mitchell, 1995: 36 dn. 105. Konu hakkında daha fazla bilgi ve değerlendirme için bk. Emir, 2014: dn. 285. Ancak Deiotaros tarafından yaptırılmış olabileceği düşünülen Bayburt Kalesi ve çevresinde gerçekleştirdiğimiz yüzey araştırmalarında Galatlara ait olabilecek hiçbir arkeolojik veriye ulaşılamasa da yüzeyde Hellenistik ve Roma dönemlerine ait birçok seramik bulunmuştur. Çiğdem ve diğerleri, 2014: 7172 .
} 
Parth Krallı̆̆ı'na karşı bölgede Roma topraklarının savunulmasında ileri bir karakol görevi üstlendi. Başlangıçta RomaParth ilişkileri, büyüyen Pontos tehlikesine karşı müttefiklik ve dostluk zemini içerisinde başlamıştır. ${ }^{33}$ Frye, ${ }^{34}$ MÖ 53 yılına kadar Romalıların Parthları büyük bir güç olarak görmediklerini bu tarihten sonra özellikle Yukarı Firat'ın Roma ile Parthlara arasında anlaşmazlık bölgesi hâline geldiğini belirtmektedir.

Kırım'da tekrar Roma üzerine saldırma hazırlığında bulunan Mithradates, 68 yaŞında öldü (MÖ 63). ${ }^{35}$ Yerine geçen oğlu II. Pharnakes babasının yolundan giderek Caesar'ın Pompeius'un yerine atadığı Anadolu baş yöneticisi Domitius Calvinus'u Nikopolis/Suşehri yakınlarında yenilgiye uğrattı. ${ }^{36} \mathrm{Bu}$ başarısından sonra eski Pontos Krallığı'nın topraklarını ele geçirip Bithynia'ya kadar sınırlarını genişletti. Pharnakes'in başarıları, Caesar'ın İskenderiye galibiyetinden sonra MÖ 47 yılında Anadolu'ya geçip Pharnakes'i Zela/Zile ${ }^{37}$ civarlarında umulmadık bir şekilde yenmesi ile son buldu. ${ }^{38}$ Eutropius Pharnakes'in de bir anlamda babasının akibetine uğradığını, savaş sonrası intihara zorlandığını ifade etmektedir. ${ }^{39}$

Caesar, Zile savaşından sonra Anadolu'da uzun süre devam edecek bir Roma hâkimiyeti tesis etmişti. Anadolu'daki siyasi varlığını güçlendiren Caesar, bir süre sonra Roma'ya dönerek devletin iç meseleleriyle ilgilenmeye başladı. Caesar (MÖ49-44) egemeni olduğu Roma dünyasında aldığı

\footnotetext{
33 Tarn, 1971: 603.

${ }^{34}$ Frye, 1962: 187-188; Frye, 1984: 233 vd.

${ }^{35}$ Liv. Perioch. 102; App. Mithr. 111; Cass. Dio XXXVII. 13; Iust. XXXVII. 2; Mommsen 1958, 262, 296; Eutropius (VI. 12), Bosch (1943: 131) ve Özsait'e (1982a: 366) göre Mithradates, oğlu Pharnakes tarafından terk edildikten sonra intihar etmiştir. Arslan'a göre Romalıların eline düşmemek için daima kılıcının k1nında taşıdığı zehirden içtiğini ancak hemen ölmediğini, yakın korumasından kendisini öldürmesini istediğini söyleyerek bu şekilde öldüğünü ifade etmektedir. Arslan, 2007: 55-506; Bu konuda ayrica bk. Ormerod-Cary 1971: 391.

${ }^{36}$ Caes. Bell. Alex. 40-41; 70; Plut. Caes. 50. 1; App. Bel. Civ. II. 91; Mithr. 120; Cass. Dio. XLIII. 46. 2-3; Suet. Caes. 37. 2.
}

ekonomik önlemlerle Roma kenti ile İtalya'da sayıları her geçen gün biraz daha artan topraksız vatandaşlara yeni geçim kaynakları bulmak için İtalya dışındaki Roma topraklarında koloniler kurarak sosyal yönden Roma vatandaşlarının sıkıntılarını hafifletmek istemiştir. ${ }^{40} \mathrm{Bu}$ politika gereği Caesar Anadolu'da, Mithradates'e karşı elde ettiği zaferden sonra, doğuda yeni düzenlemelere gitti. Bu amaçla Armenia Minor'u Galatya ve Kappadokia Krallıkları arasında bölüştürerek bölge savunmasını güçlendirdi. ${ }^{41}$ Görüldüğü gibi, Gümüşhane'nin batısına kadar olan bölge bu dönemde tamamen Roma egemenliği altına alınmıştır (bkz. harita 2). Bununla beraber Bayburt ve çevresinin bu dönemlerde hâkimiyet altına alındığını gösteren kesin bir kayıt bulunmamaktadır. Yalnız Caesar döneminde, Gümüşhane ve Bayburt bölgesi, Trapezos'a ulaşan karayolunun önemli bir güzergâhını oluşturması nedeniyle doğudan Kelkit Vadisi üzerinden gelebilecek Parth saldırılarına karşı bir tampon bölge olarak düzenlenmiş olmalıdır.

Caesar'ın öldürülmesinden sonra bölgede başlayan Parth yayılmacılı̆̆ına karşı, Roma Cumhuriyet'i adına egemenliğini sürdüren Antonius, Parthlara karşı bir sefer düzenledi. MÖ 36 yılında Armenia'yı ele geçirmeyi başardıysa da MÖ 34 yılında sefer başarısızlıkla sonuçlandı. ${ }^{42}$ Antonius bu seferler sırasında, MÖ 39 yılında yaptı̆̆ı düzenlemelerle Parthlara karşı bir tampon bölge görevi üstlenecek vasal krallıklar kurdurmuş, II. Pharnekes'in oğlu Darius’a

\footnotetext{
37 Zela Roma tarafından kent ya da ticaret merkezine dönüştürülmüştü; ancak Roma dönemi öncesi kutsal araziler olarak yönetiliyordu. Pontoslular önemli konularda yeminlerini burada ediyorlardı. Sökmen, 2006: 121,125.

${ }^{38}$ Caes. Bell. Alex. 74-77; Plut. Caes. 50; Mithr. 120; Cass. Dio XLII. 47-48; Roma senatosuna bu durumu veni, vidi, vici (geldim, gördüm, yendim) kelimeleriyle bildirmiştir. Plut. Caes. 50; ayrıca bk. Goldsworthy, 2014: 504

39 Cass. Dio XLII. 45; Eut. VI. 22; 59; Sullivan, 1980: 915.

40 Magie, 1950: 414-415; Mitchell, 1993: 36-37.

${ }^{41}$ Mitchell 1993: 36.

${ }^{42}$ Plut. Ant. 39-40; Dios Cass. XLIX. 25; Frye, 1984:

235; Cornell-Matthews, 1988: 74.
} 
da Pontos Krallığ verilmiştir. ${ }^{43}$ Yine Antonius, Parthlara karşı yapacağı mücadele için büyük miktarda askerî bir güce gereksinim duymakta idi. Bu ihtiyacı İtalya'dan karşılayamadığından Küçük Asya yerlilerinden legionlar ${ }^{44}$ oluşturmaya başladı ve büyük bir varlığa ulaşan 52 legion askerini yerleştirmek için yeni kentler kurdu. ${ }^{45}$ Elimize bu konuda bir kanıt bulunmamasina rağmen büyük bir olasılıkla Satala askerî garnizonunun temelleri bu dönemlerde atılmış olmalıdır. Böylece Gümüşhane ve Bayburt bölgesi Anadolu'nun kuzeydoğusunda çok önemli bir askerî garnizon olma görevini üstlenmiştir. Daha önceleri yap1$\operatorname{lan}^{46}$ ve $2008^{47}$ yılından itibaren de çalışma ekibimizle bölgede gerçekleştirdiğimiz yüzey araştırmalarında, Bayburt ili ve çevresinde Bayburt Kalesi, Saruhan Kalesi ${ }^{48}$ gibi askerî yerleşimlerin yanı sıra sivil yerleşim alanlarının da olduğunu kanıtlayan birçok yerleşim alanı tespit edilmiştir. (Bk. Resim 1, 2). ${ }^{49}$

\section{Roma İmparatorluk Dönemi'nde Bay- burt ve Çevresi}

Roma İmparatorluk dönemini başlatan Augustus ile birlikte Roma'nın Doğu politikası
Parthlarla olan ilişkilere göre şekillenmekteydi. Zira Roma Cumhuriyet döneminden itibaren başlayan Roma-Parth mücadelesinde bir ara Antakya'ya kadar gerileyen Roma, daha sonraları Augustus'un Anadolu'ya gelip Parthların eline geçen Roma sancaklarını ve askerlerini geri alarak tekrar Parthlar'a karşı üstünlük sağladı (MÖ 20). ${ }^{50}$ Kaya, ${ }^{51}$ Augustus'un Parthlara üstünlük sağlamasıyla Crassus'un Kharrhai Savaşı'ı (MÖ 53) kayıplarını giderdiği gibi, kendisi için bölgede ikincil bir problem olan Armenia Krallığını tekrar Roma kontrolüne alarak Roma'nın doğudaki prestijini sağlamayı düşündüğünü ifade etmektedir.

Augustus Roma'nın Anadolu'da varlı̆̆ını devam ettirmesi için, doğuda Fırat'a kadar uzan imparatorluk sınırlarının sürekli elde tutulması gerekliliğine inanmış, ölümünden sonra ardıllarına bıraktığı vasiyetnamesinde bile bu konuya özellikle dikkat çekmiştir..$^{2}$

MÖ 26 yılında Augustus tarafından Pontos'a vasal kral olarak atanan Polemon'un ölmesi üzerine, karısı Pythodoris ${ }^{53}$ Kappa-

rine bulunan bu kale, vadi seviyesinden $170 \mathrm{~m}$ yüksekliktedir. Doğu ve güneydoğu yönünde girişleri vardir. Kabaca düzeltilmiş kesme taşla hem harçlı hem de harçsız olarak duvar örgüsü yapılmıştır. Güneybatı yönündeki kiplopik duvar örgüsü 10x4.5 m boyutlarındadır. Bu duvar örgüsü Erken Demirçağ özellikleri sergiler. Kale 86x20 m ebatlarındadır. Çiğdem-Özkan-Yurttaş, 2015: 163-164.

492008 yılında itibaren Bayburt ve çevresinde yapılan yüzey araştırmarında Roma dönemine ait birçok sivil yerleşim alanı tespit edilmiştir. Bunlardan bazıları; Guguluk Tepe, Örenler Mevkii, Çayılrıtepe, Baltakaya, Eski Köy Yeri Tepe (Çiğdem-Yurttaş-Özkan, 2014, 71 vd.); Çorak Höyük, Tepeçik Höyük, Kemer Taşı Höyük, Çimen Tepe Höyük, Taşkesen Höyük (ÇiğdemYurttaş-Özkan, 2015: 119 vd.); Tandır Kaya Höyük'tür Çiğdem-Yurttaş-Özkan, 2016: 163 vd.

${ }^{50}$ Suet. Aug. 21.3; Tiber. 9; Strab. XVI. 1. 28; Vell. II. 91; Dio Cass. LIV. 8; ayrıca bkz. Frye, 1984: 235.

${ }^{51}$ Kaya, 2004: 81vd

${ }^{2}$ Gibbon, 1987: 23

53 Strabon (XII. 3. 29), "Kolkhis'e kadar Tibaranoi ve Khaldia ülkesi ile Pharnakeia ve Trapezus, akıll ve devlet işlerinde tecrübeli bir kadın olan Pythodoris tarafından yönetilir" cümlesiyle Strabon, kraliçe Pythodoris"den devlet yönetiminde son derece başarılı bir kadın olarak söz etmektedir. 
dokia'nın vasal kralı Arkhelaos ile evlenir.54 Böylece Roma eyaletlerinin doğusunda, Roma ile bu devirlerde Firat Irmağı'nın güneydoğusunda bulunan Parthlar arasında, Orta ve Güney Karadeniz sahilinden başlayan, Pontos, Kappadokia, Kommagene ve Kilikia vasal krallıklarının topraklarıyla Akdeniz'e kadar uzanan geniş bir alanda tampon bölge oluşturulmuştur. ${ }^{55} \mathrm{Bu}$ arada doğuda Roma-Parth ilişkilerinde MS 16 yıllarına gelinceye kadar Roma üstünlüğünün daha belirginleştiğine tanıklık etmekteyiz. ${ }^{56}$

M. S. 38 yılına kadar Bayburt çevresinin de dâhil olduğu Pontos Krallığı I. Polemon'un eşi kraliçe Pythodoris tarafından yönetilmeye devam etti. ${ }^{57}$ Ancak kraliçe Pythodoris'un MS 38'te ölmesi ile krallığın başına torunu II. Polemon (MS 38-63) geçti. ${ }^{58} \mathrm{Ku}$ zeydoğu Anadolu Bölgesi'nde Roma'ya bağlı vassal bir krallık durumunda olan Polemon Krallığı II. Polemon döneminde en büyük sınırlarına ulaşmıştı. Çünkü dönemin Roma İmparatoru Caligula MS 14'te Bosporos Krallığı'nı da kendisine bağışlamışt1. ${ }^{59}$ Böylelikle Polemon Krallığg'nın s1nırları, Kuzeyde Kırım Yarımadası ile birlikte Anadolu'da Karadeniz kıyısı boyunca Amisos'tan Kolkhis'e, iç kesimlerde Zela'dan Armenia'nın kuzey sınırlarını oluşturan dağlara kadar uzanmıştı.

İmparator Nero (MS 54-68)'nun MS 54'te Roma İmparatorluk tahtına çıkması Anadolu'nun doğu ve kuzeydoğu Anadolu bölgeleri siyasi ve askerî olarak yeniden hareketlendi. Zira İmparator Nero, Doğu'da Armenia ve Parthlara karşı büyük bir sefer kararı aldı. MS 58 yılında Armenia ve Parth Kralı Tridates'e karşı yaptığı sefer sırasinda Trapezos/Trabzon'un Romalıların

54 Sullivan, 1971: 120; Mitchell, 1993: 94; Kaya, 2005a: 81.

55 Özsait, 1982b: 384 .

${ }^{56}$ Tac. Ann. II, 1-4; Frye, 1984: 236-237.

57 Magie, 1950: 494; Cornell- Matthews, 1988: 150151; Emir, 2014: 143.

${ }^{58}$ Cass. Dio LIX. 12; ayrica bkz. Jones, 1969: 170-171.

59 Magie, 1950: 514; Olshausen, 1980: $911 \mathrm{vd}$.

6o Tac. Ann. XIII, 39; Cumont, 1923: 111; Özsait, 2ooob: 41. ikmal üssü olduğu görülür. ${ }^{60}$ Dolayısıyla Romalılar Anadolu'nun iç bölgelerine geçerken Gümüşhane ve Bayburt bölgesini de kullanmaları kaçınılmaz olmuştur.

Parthların Armenia üzerinde egemenlik sağlamaları üzerine, Roma nüfuzunu doğuda yeniden kurmak için başaltılan savaşın kumandası, devrin en iyi komutanlarında Cn. Domitius Corbulo'ya verilmiştir. ${ }^{61}$ Mitford, bu savaşlar sırasında Roma ordusunu kumanda eden Corbulo'nun Ksenophon gibi bugünkü Gümüşhane il merkezinin bulunduğu güzergâha uğramadan Tekke üzerinden Maçka'ya ulaştığını ve bu yolu onardığını belirtmektedir. ${ }^{62}$ Bosworth'a $^{63}$ göre de Corbulo, seferine muhtemelen Satala'dan başlamıştır. Böylelikle Corbulo, daha sonra Satala'nın da önemli bir rol oynayacağ1, doğudaki düşmanlarına karşı oluşturulacak olan Fırat Hattı'nın da temellerini atmıştır. ${ }^{64}$ Corbulo bu savaşlarda önemli başarılar göstermiş, ${ }^{65}$ Parth kralı Tridates'i mağlup ederek büyük bir galibiyet elde etmiştir. ${ }^{66}$ Corbulo Erzurum/Elegeia ile Gümnüşhane ve ötesine geçişte Kop-Bayburt güzergahını takip etmesi kaçınılmaz olmuştur. ${ }^{67}$ Daha sonraki yıllarda (MS 63) Nero, Pontos Kralı II. Polemon'un ölümünden sonra, topraklarının Roma'ya terk edilmesi üzerine, Pontos Polemoniakus ile Pontos Galatikus'u Galatia Eyaletine bağladı. Böylece Karadeniz'in güney kıyıları doğrudan doğruya Roma yönetimi altına girdi, Kommagene Krallığı ve Küçük Armenia dışında kalan bütün Küçük Asya toprakları Roma'ya bağlanmış oldu ${ }^{68}$ (Harita 3).

İmparator Vespasianus (MS 69-79) döneminde gerçekleştirilen imar faaliyetleri

\footnotetext{
${ }^{61}$ Tac. Ann. XIII. 8; ayrica bkz. Gilmartin, 1973: 584 vd.; 164; Frye, 1984: 239; Isaac, 1990: 29; Bivar, 1983: 81.

62 Mitford, 2000: 128.

${ }^{63}$ Bosworth, 1983: 271.

${ }^{64}$ Yorke, 1896: 469.

65 Tac. Ann. XV, 25; Mitford, 2018: 32.

${ }^{66}$ Cass. Dio LXII. 23; Tac. Ann. XIV. 23 vd.; ayrıca bk.

Chaumont, 1976: 105-106; Chahin, 1987: 246.

${ }^{67}$ Çiğdem, 2011: 99.

68 Suet. Nero, 18; Eutr. VII. 14; ayrica bk. Mitchell, 1993: 63; Jones, 1969: 171; Özsait, 1982b: 388.
} 
içersinde Roma'nın deniz üssü olan Trabzon/Trapezos ile Satala arasinda son derece önemli bir yol yapılmış, böylece Kelkit ve Çoruh vadisine açllan bu yolla Trapezos'un hinterlandı ile bağlantıları sağlanmıştır. ${ }^{69}$ Bu yolla Fırat'ın batı yakasında Parthlara karşı konuşlandırılan legionlar arasında bağlantılar sağlandığı gibi, Samsat/Samosata'ya kadar deniz yolu ile askeri güçlerin kolayca ulaşması da mümkün kllınd1. ${ }^{70}$ Yine İmparator Vespasianus döneminde yapılan bir düzenleme ile Galatia ve Kappadokia eyaletleri birleştirilerek yönetim tek bir imparatorluk legatına bırakılmış, bu büyük eyaletin sınırları kuzeyde Orta ve Doğu Karadeniz'in kıyı kesiminin yanında Firat Irmağı sınır olacak şekilde Güneyde Suriye Eyaleti'ne kadar uzanmıştır. ${ }^{71}$ Satala'ya da XVI Flavia yerleştirilmiştir. ${ }^{72}$ Zira tarafımızdan da yüzey araştırmalarında keşfedilen ${ }^{73}$ legion mühürlerinde XV. Flavia Firma'nın burada olduğu kanitlanmaktadır. ${ }^{74}$

Vespasianus, bölgede yaptığı bu düzenlemelerle doğuda vasal kralların insiyatifine terkedilmiş olan emniyet ve sükûnu, buralara yerleştirilen Roma legionlarının varlıkları ile temin etme yoluna gitmiş, böylece doğudan gelecek olan Parth saldırılarına karşı güneyde Malatya/Melitene, Samsat/Samosata, kuzeyde de Satala önemli bir stratejik konuma ulaşmışlar-

\footnotetext{
${ }^{69}$ Yorke, 1896: 470; Cumont, 1923: 113-114; Mitford, 1974b: 16o; Özsait, 20oob: 41.

${ }^{70}$ Arthur-Munro, 1901: 62.

${ }^{71}$ Bosworth, 1976: 63 vd.; Özsait, 1982b: 389.

${ }^{72}$ Syme, 1977: 39.

732004 yılı çalışmalarımızda bir kısmının üzerinde buradaki askeri garnizona ait olduğunu gösteren legion yazısının bulunduğu 12 adet mühür ele geçirilmiş ve Gümüşhane kültür müdürlüğüne teslim edilmiştir. Mühürlerinin uzunluğu 5-17 cm, genişlikleri $11-5 \mathrm{~cm}$ ve kalınlıkları da $2-2.5 \mathrm{~cm}$ arasında değişmektedir. Çiğdem, 2008: 80 dn. 451.

${ }^{74}$ French, 1994: 44-45.

75 Emir, 2014: 158-159.

${ }^{76}$ Yorke, 1896: 470; Payne, 1970: 240-241; CornellMatthews, 1988: 103; Bennett, 2005: 194 vd.; Griffin, 2008: 124 .

${ }^{77}$ Cass. Dio LXVIII 19. 2; Eutr. VII. 3; ayrıca bkz. Stark, 1966: 201; Bosworth, 1977: 227; Mitford, 1980: 1198.

${ }^{78}$ Lightfoot, 1990: 117.

${ }^{79}$ Lightfoot, 1990: 117.
}

dır. ${ }^{75}$ Öyle ki Roma'da gerekli düzenlemeleri yaptıktan sonra Büyük İskender'e öykünerek ${ }^{76}$ ilk Parth seferine (MS 114) çıkan İmparator Traianus (MS98-117), son hazırlıklarını Satala'da gerçekleştirmiştir. ${ }^{77}$ Lightfoot, ${ }^{78}$ Traianus'un bu sefere çıkarken öncelikli amacının Danube ve Kappadokia'dan gelen takviye güçlerle karşılaşacağı Satala'ya ulaşmak olduğunu belirtmektedir. Yine Lightoot'un hesaplamasiyla muhtemelen Nisan başında, günde yaklaşık olarak $15 \mathrm{~km}$ yol alan Traianus, aşağ 1 yukarı 51 günlük bir seyahatin sonrasında Satala'ya ulaşmıştır. ${ }^{79}$ Traianus kendine bağlı Kafkas krallarını Satala'da kabul ettikten $^{80}$ sonra, Haziran başında Bayburt üzerinden ulaştığ 1 Erzurum/Elegeia'dan ${ }^{81}$ düşmanı üzerine yürümüştür. Sefer sonucunda Traianus, Armenia'yi Roma eyaleti hâline getirmiş, ${ }^{82}$ Parth topraklarına girerek burayı vasal bir krallık olarak Roma'ya bağlamıştır. ${ }^{83} \mathrm{Bu}$ arada Legio XV. Apollinaris sürekli kalmak üzere Satala'ya yerleştirerek $^{84}$ bölgeyi doğudan gelebilecek sald1rılara karşı güvence altına almıştır. ${ }^{85}$ Zira tarafımızdan da bölgede yapılan yüzey araştırmalarında keşfetilen legion mühürleri XV. Apolloninaris legionu ve Traianus'un Satala'daki varlığını doğrulamaktadır. ${ }^{86} \mathrm{Bu}$ mühürlerin bazılarında "Leg. $X V$.

\footnotetext{
${ }^{80}$ Cass. Dio. LXVIII. 19. 2; ayrica bk. Merrill, 1901: 60; Chaumont, 1976: 133. Bosworth bu toplantının Satala'da değil, Elegeia'da yapıldığını ileri sürmektedir. Bosworth, 1977: 227.

${ }^{81}$ Elegeia Erzurum'un $15 \mathrm{~km}$. batısına lokalize edilmektedir. Longden, 1931: 2-3, 9; Lightfoot, 1990: 117. Lokalizasyonla ilgili olarak ayrıca bk. Çiğdem, 2011: $105 \mathrm{vd}$

${ }^{82}$ Kral Parthamisiris Traianus'a mektup göndererek Elegeia'da buluşma teklifinde bulundu yapılan görüşmeden Parthamisiris tacını Traianus'un ayakları altına bırakarak savaşmadan ülkesini Roma'ya teslim etti. Cass. Dio LXVIII. 19. 2-3; ayrıca bk. Chahin, 1987: 250; Frye, 1984: 242; Campbell, 1993: 235; Bivar, 1983: 88; Çiğdem, 2011: $101 \mathrm{vd.}$

${ }^{83}$ Frye, 1984: 242; Mommsen, 2005: 288-290; Aiston, 2005: 151.

${ }^{84}$ Yarlıgaş, 2016: 128 vd. ; ayrıca bk. M’Elderry, 1909: 47.

${ }^{85}$ Syme, 1977: 42.

${ }^{86}$ Çiğdem, 2008: fig. 179, 180.
} 
Apol" yazmaktadır. ${ }^{87}$ Öyleki XV. Apollanaris legionu ilk kez imparator Nero döneminde genaral Corbulo'nun denetiminde Doğu seferleri için bölgeye kaydırıldığı bilinmektedir.

Traianus'tan sonra Roma tahtına geçen Hadrianus (MS 117-138), halefinin politikalarını takip etmiştir. Roma'nın daha fazla yayılmaması gerektiğine ve ele geçirilen toprakların Roma tarafindan idare edilmesinin zorlaşacağına inanan imparator, bu politikaya uygun olarak doğunun düzenlenmesiyle meşgul oldu ve Armenia'yı Parth Kralı Vologases'e iade ederek burasını bir vasal krallık şekline getirdi..$^{88}$ Hadrianus'la Parth'lar kendi krallarını seçme hakkını yeniden kazandılar. Hadrianus'un isteğiyle Armenia, Asur ve Mezopotamya'da garnizonlar hâlinde bulunan Roma birlikileri yerlerini terk ettiler ve böylece Frrat eskisi gibi imparatorluğun doğu sınırı hâline geldi. ${ }^{89}$

İmparator ülkesinin doğu bölgelerine çıtığ 1 ilk gezisinde (121-125) Tarsus, Tyana/Kemerhisar, Melitene üzerinden kuzeye geçerek Trapezos üzerinden Doğu Karadeniz kıyılarını takip ederek Bithynia'ya geçmiştir..$^{\circ 0} \mathrm{Bu}$ yolculuğunda Hadrianus Trapezos'a Bayburt-Gümüşhane üzerinden ulaşmış olmalıdır. Mitford, Satala'dan yola çıkan Hadrianus'un Bağdat Yolu olarak bilinen Köse-Yurtlar DeresiHurusufla üzerinden Harşit Vadisi'ne geçtiğini, buradan Zigana Geçiti'ni kullanmadan yoluna devam ettiğini ifade etmektedir. ${ }^{91}$ Bundan sonra gerçekleştirdiği ikinci gezisinde de (MS 128-133) Karadeniz sahillerinde Trapezos, Amisos/Samsun ve Amasia'yı gezdikten sonra MS 131 yılı sonbaharında veya MS 132 'de Atina'ya geçti..$^{22}$ Hadrianus'un gerçekleştirdiği ikinci gezisinde de Trapezos'a ulaşmak için Bayburt ve Gümüşhane çevresinden geçmiş, muhtemelen Satala'da Iberia kralı II. Pharasmanes ile bölgenin statüsünü görüşmek için bir toplantı yapmak istemişse de Pharasmanes onun bu görüşme davetini kabul etmemiştir. ${ }^{93}$ Hadrianus bu ikinci gezisinde daha çok Satala'nın askeri ihtiyaçlarını deniz yolundan kolaylıkla sağlanmasını göz önüde tutarak Trapezos'a bir liman da yaptırmıştır. ${ }^{94}$

Hadrianus'un Kappadokia valisi olarak görev yapan Arrianus MÖ 134 yllında, Kazakistan steplerinin yükselen gücü Alan ${ }^{95}$ kavmine karşı Satala'da konuşlanmış olan legio XV. Apollinaris ile Melitene'de konuşlanmış olan legio XII. Fulminata'nın başında sefere çıkmış, Alan tehlikesini bertaraf etmiştir. ${ }^{6}$ Arrianus yaptığı çalışmalarla Alanları uzun bir süre Anadolu için tehlikeli bir unsur olmaktan da çlkarmıştır. Arrianus bundan sonra Doğu Karadeniz'de ve Kafkaslar'da gerçekleştirilecek bütün operasyonlar için Satala'yı bir koordinasyon merkezi hâline getirmiştir. ${ }^{97} \mathrm{Bu}$ arada Arrianus en son Vespasianus'un yaptığ 1 düzenlemelerden sonra doğudaki emniyetin ihmal edildiğini, buradaki güvenliğin yalnız Satala ve Melitene'ye bırakıld1ğını görmüş, bu açı̆̆ı kapatmak için Kafkaslara doğru bölgede yer alan bütün vasal

\footnotetext{
87 Yorke, 1998: 306: 321-322 no.16.; French, 1994: 4445. Cumont kardeşlerin de yaptıkları araştırmalar Leg. $X V$ ya da Leg. $X V$. AP. yazılı tuğla mühürlerin Satala'ya Roma'nın uzun bir süre hâkim olduklarını göstermektedir. Cumont - Cumont, 1906: 345 .

88 SHA Hadr. 21; ayrica bk. Cumont, 1936: 609; Chahin, 1987: 250; Mitford, 1980: 1200;

89 Eutr. VII. 4; Pelham, 1896: 631; Gibbon, 1978: 27; Payne, 1970: 242.; Eutropius (VIII. 6), Hadrianus'un, halefi Traianus'u kıskandığı ve onun bu büyük başarılarını hazmedemediği için onun imparatorluğa dâhil ettiği üç eyaletten (Assyria, Mezopotamya ve Armenia) vazgeçtiğini belirtmektedir. Buna karşın

Mommsen (2005: 290), Roma'nın doğudaki bu sınırları denetleyecek gücü olmadığı için Hadrianus'un böyle bir karar aldığını ifade etmektedirler.

90 Magie, 1950: 621; Bryer-Winfield, 1985: 180; Syme, 1988: 161; Boatwright, 2008: 165-166.

${ }^{91}$ Mitford, 200o: 128.

${ }^{22}$ Cumont ve Cumont, 1906: 365; Boatwright, 2000: 119

93 SHA Hadr. 21; ayrica bk. Bosworth, 1977: 228; Braund, 1994: 232; Birley, 2008: 143.

94 Winfield, 1977: 155; Boatwright, 2000: 119.

95 Czeglédy, 1999: 141.

${ }^{96}$ Debevoise, 1966: 242 vd.; Bosworth, 1977: 228; Alemani, 2000: 108-109; Sarıkaya, 2013: 331, dn. 22.

${ }^{97}$ Bosworth, 1977: 234.
} 
krallıklarla diplomatik ilişkiler kurmuştur..$^{98}$

Marcus Aurelius (MS 161-180) ve manevi kardeşi Lucius Verus'un (Lucius Annius Antoninus Verus) (MS 161-169) saltanat yıllarında Romalılarla Parthlar arasında tampon devlet konumunda olan Armenia'nın kontrolu, tekrar bir sorun hâline geldi. Parth kralı IV. Vologases'in (Valgash) (MS 147-191) kuvvetleri MÖ 161'de Cappadocia valisi Sedatius Severianus'u Elegeia'da mağlup edip legionunu tamamen yok etti ve Armenia tahtına kendi adayı olan Pacorus'u geçirterek kontrolü eline aldı. ${ }^{99}$ Doğudan gelen bu kötü haberler karşısında Verus'a savaş için yüksek yetkiler verilerek bölgede kaybedilen legionların yerini doldurmak için yeni kuvvetler toplandı. ${ }^{100}$ Verus'un rahatsızığı nedeniyle daha çok komutanlarının idare ettiği savaşlarda Armenia'nın başkenti Araxata tahrip edilip yerine Kainepolis kenti kuruldu (MS163) ve Armenia tahtında bulunan Pacorus indirilerek yerine Soaemus getirildi. ${ }^{101}$ Satala'da konuşlanan Minervia I legio'su Armenia'nın işgal edilmesinden sonra Doğu Karadeniz Bölgesin'den Kafkaslara yöneldi. Daryal geçidini de aşarak Hazar kıyılarına kadar ilerledi. Emir, Roma legio'sunun bu bölgeye kadar ilerlemesini muhtemelen Pontos Bölgesi'ni sürekli taciz eden Alanların cezalandırılmasına yönelik bir hareket olarak yorumlamaktadır. ${ }^{102}$ Ancak bu keşif seferi hakkında kaynaklarda fazla bilgi bulunmamaktadir.

Septimus Severus (193-211) Traianus'tan sonra tekrar Fırat Irmağı'nın çok ötesine geçmiş, 18 yıllık saltanatının büyük bir kısmını doğu savaşlarında geçirmiş, ilk dört

\footnotetext{
$9^{8}$ Syme, 1982: 200-201.

99 Cass. Dio LXXI. 2. 1; ayrıca bk. Bivar, 1983: 93; Frye, 1984: 243; McLynn, 2009: 137; Birley, 2012a: 14; 2012b: 217.

${ }^{100}$ Çiğdem, 2011: 103.

101 Bokşçanin, 1966 II, 269 vd.; Bivar, 1983; 93; Chahin, 1987: 251; Farrokh, 2007: 165-166; Birley, 2008: 162

${ }^{102}$ Emir, 2014: 173.

103 Kaya, 2006: 28-29.

${ }^{104}$ Kaya, 2006: 45.
}

savaşını da Anadolu sınırları içerisinde gerçekleştirmiştir. ${ }^{103}$ Yaptığ 1 savaşlar sonucunda bütün Anadolu kentlerini kendisine bağlayan Septimus Anadolu'da yeni bir kent kurmadığ 1 gibi kentlere imparatorların adlarının verilmesi geleneğini de terk etmiştir. ${ }^{104} \mathrm{Bu}$ dönmede Bayburt ve çevresi de Parth tehditinden uzak Roma egemelik sınırları içerisinde bulunmuş olmalidir.

Roma İmparatorluğu'nun Parthlar'la olan mücadelesi, İmparator Severus Alexander (MS 222-235) döneminde, Aradaşir/Artaxerxes önderliğinde Parthlar'ın ortadan kaldırılıp ${ }^{105}$ yerlerine Sasani Devleti'nin kurulmasına kadar devam etmiştir. ${ }^{106}$

Bundan sonra Roma, doğuda egemenlik için Sasanilerle mücadele etmeye başlamıştır. Bir ara Küçük Asya, doğudan Sasani batıdan Goth saldırılarıyla yağmalanmış, bütün limes'ler (Roma'nın tahkimli sınır boyları) tahrip edilmiştir. ${ }^{107}$ Sasani Şahı Şapur'un MS 252 yılındaki seferi sonucunda, Sasanilerin eline geçen kale ve kentler arasında Satala da bulunmaktadir. ${ }^{108}$

İmparator Claudius Tacitus döneminde (MS 275-276) Karadeniz'in kuzey kıylarından gelen Maeotidlerin saldırıları Anadolu içlerine kadar uzanmış, Karadeniz'le beraber Galatia, Kappadokia ve hatta Kilikia'ya kadar ilerlemiştir. ${ }^{109}$ Maeotidlerin saldırılarına karşı sefere çıkan imparator, kardeşi Florianus'un yardımıyla önemli bir zafer kazanmıştır. ${ }^{110}$

Claudius Tacitus'un MS 276'da öldürülmesinden MS 284'te Aurelianus Valerius Diocletianus dönemine kadar Roma İmparatorluk tahtına çıkan M. Aurelius Probus

\footnotetext{
${ }^{105}$ Eutr. VII. 23; 219; Frye, 1984: 290-291.

${ }^{106}$ Gibbon, 1987: 219; Christensen, 1936: 13 vd.; Özsait, 1982b: 394; Frye, 1984: 244.

${ }^{107}$ Callistus Sasanileri Cilicia'da Corycus'ta (Kızkalesi karşısı) beklenmedik ani bir mağlubiyetle durdurulabildi. Özsait, 1982b: 394-396; Frye, 1984: 297-298; Gibbon, 1987: 260 vd.

${ }^{108}$ Dodgeon-Lieu, 1991: 50, 363 dipnot 19.

109 Zos. Nov. Hist. I. 63; Zon. XII. 28; ayrıca bkz. Mitford, 1980: 1208; Drinkwater, 2008: 54 .

${ }^{110}$ Magie, 1950: 720-721; Gibbon, 1987: 345 vd.
} 
(MS 276-282) ve Aurelis Carus (MS 282MS 283) dönemlerinde Bayburt ve çevresi hakkında kayıtlara geçen önemli bir siyasi gelişme yaşanmadı ̆ı tahmin edilmektedir. MS 288 yılında Armenia üzerinde etki kurmak isteyen kral Vahram, Roma hâkimiyetini tanımak zorunda kalmış ise de doğuda Sasani saldırıları bundan sonra da durmaksızın devam etmiştir. ${ }^{111} \mathrm{Bu}$ yıllarda aralıksız devam eden Roma-Sasani savaşlarında, ${ }^{112}$ bölgenin nasıl bir konumda olduğunu gösteren bilgilerden oldukça yoksunuz.

MS 363 yılı doğu sınır hattını ayrıntılarıyla tanımlayan Honigmann, Satala'ya kadar bütün sınır istihkâmlarının Fırat'ın batı sahilinde veya bu kıyıya yakın bulunduğunu, Satala'dan itibaren sınır hattının Pontos silsilesi üzerinden Karadeniz'e uzandığını ifade ederek ${ }^{113}$ Satala'nın bu yıllarda da Roma için bir stratejik konumda olduğunu ortaya koymuştur. Bu arada MÖ 363'de Romalllar, Artaxata ve bunun ötesindeki araziden feragat etmek zorunda kalmışlardir. ${ }^{114}$

\section{Doğu Roma Döneminde Bayburt ve Çevresi}

MS 395'de Roma İmparatorluğu ikiye ayrılinca ${ }^{115}$ Gümüşhane ve Bayburt bölgesi Doğu Roma (Bizans) sınırları içersinde kalmıştır. Sasaniler de Roma'nın doğudaki en önemli rakibi olmaya devam etmişlerdir. Nihayet Anadolu'nun doğusu ve kuzeydoğusu üzerine devam eden Doğu Roma-Sasani mücadeleleri iki devleti Satala önlerinde kıyasıya bir savaşa sürüklemiştir.

MS 502 yılında Mermeros komutasındaki Sasani ordusu ile Sittas ve Dorotheus ko-

\footnotetext{
${ }^{111}$ Akşit, 1970: 217, 220 vd.; Özsait, 1982b: 399 vd.; Baydur, 1982: 108 vd.; Dodgen-Lieu,1991: 34 vd. ${ }^{112}$ Gibbon, 1987: 388 vd.

${ }^{113}$ Honigmann, 1970: 5. Bu dönemde Karadeniz üzerinden batı dünyası ile İran arasında önemli ticari bağlantılar da kurulmuştur. Curzon, 1966: 530.

${ }^{114}$ Honigmann, 1970: 4; Armenia ve Iberia (Gürcistan) bölgelerinin doğrudan doğruya Roma arazisi olmayıp yalnızca Romalıların askerî himayesinde yer almışlardir. Honigmann, 1970: 4

${ }^{115}$ Gibbon, 1988: 28 vd.
}

mutalarındaki Roma ordusu arasında meydana gelen savaşta Satala çok önemli bir rol üstlenmiştir. Satala ve çevresine konuşlanan Roma ordularına karşı, Mermeros'un saldırısıyla başlayan bu savaşla ilgili Prokopius bize şu bilgileri vermektedir:

Mermeros ordusunu toplayıp Roma topraklarına saldırdı ve Satala şehri yakınında düşmanları ile karşı karşıya geldi. Şehrin 56 stades uzaklığında ve Octava denilen bölgede kamp kurdular. Bu nedenle Sittas bin adamı ile Satala şehrinin de içinde bulunduğu ovayı çepe çevreleyen tepelerin arkasina gizlendi. Dorotheus askerlerin geri kalanı veya kendi emri altındaki ordu ile içerde tahkimatların arkasında kaldı. Düşman ile düz alanda karşılaşmak istemiyorlardı. Çünkü düşman 30.000 den aşağı değildi ve kendilerinin sayısı da hemen hemen bunların yarısı kadardı. Takip eden günlerde barbarlar surların önüne kadar geldi ve şehri kuşatma altına aldı. Ama Sisttas'ın adamları hızla tepelerden aşağı inmeye başladılar. Yaz zamanı ortaya çıkan sis yüzünden sayılarının görülmesi olanaksızdı. Bu nedenle düşmanlar onların çok kalabalık olduğunu düşündüler ve planlarında vazgeçip kuşatmayı kaldırdılar... ${ }^{116}$

Satala önlerinde göğüs göğüse devam eden mücadelelerden sonra Sasaniler geri çekilmek zorunda kalmışlardır. ${ }^{117}$

I.Iustinianus (MS527-565) döneminde imparatorluğun kuzeydoğu politikası içerisinde, Sasanilerle yapılan "ebedi barışa" rağmen, İran saldırılarına karşı sınır güvenliğinin sağlanması amacıyla alınan önlemler arasinda Melitene, Koloneia ve Theodosiopolis gibi önemli kentlerdeki müstemlekelerde yapı ve onarım faaliyetleri yer alır. Bununla ilgili olarak Prokopius Iustinianus tarafından bölgede birçok kale ve gözetleme kulesi yaptırıldığını ya da

\footnotetext{
${ }^{116}$ Proc. bell. I. XV. 9-17. Karadeniz'i de ziyaret eden Prokopius'un Bayburt'tan Trabzon'a giderken bugünkü Gümüşhane-Trabzon güzergâhını kullanmadan Soğanlı Dağlarını aşarak Madur Tepesi'nin eteklerinden kuzeybatıya, Trapezos yönüne doğru yoluna devam ettiği sanılmaktadır. Zehiroğlu, 2000: 103-104. 117 Bu savaşlarda Theodosiopolis (Erzurum) da Sasaniler tarafından işgal edilmiştir. Frye, 1984: 323; Adontz, 1970: 109-111.

${ }^{118}$ Ylldiz, 1982: 492-493.
} 
onartıldığını belirtmektedir. Erzurum ile Gümüşhane illeri arasında Prokopius'da geçen fakat bugün lokalizasyonlarını tam olarak belirleyemediğimiz "Horonon", "Tzuomina” gibi birçok sivil ve askerî stratejik yapılardan söz edilmekte ve bu yapıların ya ilk kez yapıldığı ya da güçlendirildiği ifade edilmektedir. ${ }^{119}$ Tarafımızca yapılan yüzey araştırmalarında Bayburt ili ve çevresinde bu üslere/yapılara aday gösterilebilecek birkaç yer tespit edilmiştir. Bunlardan ilki Alavlu Düzü'dür. Bayburt'ta Merkez ilçe sınırları içerisinde yer alan Yeniköy'ün $5 \mathrm{~km}$ batısında, Alavlu Düzü ismiyle bilinen yaklaşık 5 hektarlık alanda bir geçici ordugâh tanzim edilmiş olduğu anlaşılmaktadır. Burası muhtelemelen Iustinianus döneminde geçici bir garnizon yeri olarak teşkil edilmiştir. Alanın kuzeybatısında Saruhan Kalesi de konumu ve yapısı itibariyle Prokopius'ta sözü edilen müstemlekelere aday yerlerdir. Öyle ki Saruhan Kalesi güneybatı yönünde OtlukbeliErzincan yolu üzerinde yer almaktadır. Alanı çepeçevre saran harçsız moloz taş duvar örgüsü bulunmaktadır. Bu şekli ile oldukça ilginç bir görünüm sergilemektedir. Sur sisteminin kuzeyi nispeten ayakta olup $1.40 \mathrm{~m}$. yüksekliğinde $2 \mathrm{~m}$. kalınl1ğında bir duvar örgüsüne sahiptir. Bu örgü kiplopik tekniktedir. Ancak yüzeyde bu sistemi tarihlendirmeye yarayacak herhangi bir buluntu ele geçirilememiştir. ${ }^{120}$

Prokopius'ta Erzurum ve Bayburt'tan sonra Satala ve çevresinde de imar faaliyeterinin yapıldığı anlatılmaktadır. Yine Iustinianus tarafından Satala kentinin de surları onarılmış, su kemeri yapılmıştır. ${ }^{121}$ Prokopius Satala ve mücavir alanda gerçekleştirilen imar faaliyetlerini şu şekilde ifade etmektedir; ${ }^{122}$

Satala Kenti, eski dönemlerde güvenilmez bir durumda idi. O düşman ülkesinden uzak olmayan bir bölgede konuşlandırıldığı, alçak

119 Proc., aed. III. V. 12-15 - VI. 1-7.

${ }^{120}$ Çiğdem-Yurttaş-Özkan, 2017: 165. Bu alanın geçici ordugâh olarak Roma Dönemi içerisinde değerlendirilmesi gerekliliği ile görüş, düşünce ve bilgilerini bizlerle paylaşan Gaziantep Müzesinde görevli Arkeolog Ahmet Beyazlar'a çok teşekkür ederiz. bir platoda uzandığı ve kulelerle donatılmış birçok tepeye olduğu için saldırılara karşı koyabilecek dolanbaçlı duvarların gereksinimiyle ayakta durabilmiştir. Kalenin bu uygun doğal çevresine rağmen, başlangıçta kötü bir işçilikle özentisiz bir şekilde yapılması dolayısıyla savunması tehlikeli bir konumda idi ve aradan uzun bir zaman geçtiği için duvarları hemen hemen çökmüştü. Ancak İmparator kalenin hepsini yıktı. Onun kule kütlesinin güvenliğini temin etmek için yeterli kalınlıkta ve onun etrafında bulunan tepelerin en üst noktasında görülebilecek kadar uzun yeni bir duvar yaptı... O aynı zamanda Satala'ya uzak olmayan Osroene olarak adlandırılan bölgede çok güçlü bir kale de yaptı.

Gümüşhane ve Bayburt bölgesi Doğu Roma-Sasani ilişkilerinde, tıpkı RomaParth ilişkilerinde olduğu gibi, önemli bir askerî karargâh olma özelliğini devam ettirmiştir. Bölge, bu mücadeleler sırasında İran saldırılarından oldukça etkilenmiştir. Bu saldırılara karşı MS 625'te sefere çıkan İmparator Herakleios (MS610-641), Kelkit Vadisi üzerinden Karadeniz kıyılarına ulaşmıştır. Bu olaylar esnasında Satala hala stratejik etkinliğini devam ettirmektedir. ${ }^{123}$ Özellikle yaz aylarında Roma ordularının Karadeniz sahiline ulaşmak için kullandıkları en önemli güzergâh Bayburt üzerinden sağlanıyordu. Satala/KelkitKöse-Demirözü-Bayburt yolu takip edilerek Aydıntepe'ye ulaşılmış, buradan Soğanlı Dağları aşılarak Karadeniz'e inilmiştir. Bryer-Winfield ${ }^{124}$ Bayburt-Trabzon yolunun Aydıntepe-Of arasında Soğanlı Dağları üzerinden $100 \mathrm{~km}$. daha kısa olduğunu belirtmektedirler. Bölgede yaptığımız yüzey araştırmlarında Bayburt ve çevresinde başta Aydıntepe Höyük ${ }^{125}$ olmak üzere birçok höyükte elegeçirdiğimiz keramik buluntuları Satala'nın doğusunda hem askeri hem sivil Roma yereleşim yerlerinin olduğu belirlenmiştir. Bayburt bir taraftan

\footnotetext{
${ }^{121}$ Prok. Bell. III. IV. 2-5; Cumont, 1906: 345; Honigmann, 1970: 17; Adontz, 1970: 117; Ostrogorsky, 1986: 95; Mitford, 2018: 356-357.

${ }^{122}$ Proc. de bell. III. IV. 2-5.

${ }^{123}$ Foss, 1975: 722.

${ }^{124}$ Bryer-Winfield, 1985: 324.

${ }^{125}$ Çiğdem, 2013: 67-68.
} 
Kop üzerinden Elegeia/Erzurum bağlantısını bir taraftan da Bayburt- Soğanlı ve Bayburt-Gümüşhane üzerinden Satala-Karadeniz bağlantısını sağlıyordu.

Herakleios döneminde, İran saldırılarına karşı alınan önlemlerin başında Anadolu topraklarında dört thema meydana getirilmiş, buralarda askeri hizmet görmek koşuluyla savaşçılara toprak verilmiştir. ${ }^{126}$ Themaların başlarına sivil yönetici olan prokonsulların da üstünde olan strategos denilen komutanlar atanmıştır. Doğu Roma döneminde Gümüşhane-Bayburt çevresi, ilk kurulduğunda Armeniakon, daha sonra da merkezi Trabzon olan Khaldia Theması içersinde yer almıştır. ${ }^{127}$ Gümüşhane ve Bayburt bölgesinin de yer aldığı Khaldia Theması daha sonraları Imparator Theophilos döneminde (MS829-842) kurulmuş, ${ }^{128}$ güneydeki sınırı Çoruh Nehri olarak belirlenmiştir. ${ }^{129}$

Burada Khaldia ismi ile bir tartışma da gündeme gelmektedir. Khalyb/Khaldia şeklinde klasik kaynaklarda geçen ve Urartu baş tanrısı Haldi'ye kadar uzanan bu isim altında, yöre tarihi ile ilgili birçok görüş ileri sürülmüştür. ${ }^{130}$ Bölgede bugüne kadar yaptığımız çalışmalarda özellikle, Urartu Devleti'nin yıkılmasından sonra, Bayburt çevresine Urartu halkının yerleştiğini gösteren herhangi bir bulgu elde edemedik. Dolayasıyla Khaldia ile Haldi arasında bir bağlantının olabileceğini söylememiz mevcut bulgularla olanaksız gözükmektedir. Şimdilik bölge ile ilgili klasik kaynaklarda geçen Khaldia ve Khalybe hakkındaki bilgileri tartışmaksızın vermekle yetineceğiz. Bölgedeki çalışmalarımızın sonunda, bu konuda daha ayrıntılı bilgileri sunmayı ummaktayı.

Strabon'da hem Khalyb hem de Khaldai isimleri geçmekte ve yazar bunlar arasında bir halef-selef ilişkisi kurmaktadır;

\footnotetext{
${ }^{126}$ Yildiz, 1982: 497; Ostrogorsky, 1986: 89-91.

${ }^{127}$ Ostrogorsky, 1986: Harita II.

${ }^{128}$ Ostrogorsky, 1986: 194.

${ }^{129}$ Honigmann, 1970: 52. Khaldia'nın sınırları ile ilgili geniş açıklama için bk. Bryer-Winfield, 1985: 299304.
}

\begin{abstract}
"Bugünkü Khaldai eskiden Khalybes denirdi ve ülkelerinin tam karşısında Pharnakia kurulmuştur. Bu denizlerde yapılan palamut avı doğanın sağladığı bir avantajdır. Bu balık ilk defa burada yakalanmıştır. Karada madenler vardır, daha eski devirlerde gümüş madenleri de olduğu halde, bugün sadece demir madeni kalmıştır. Bu bölgedeki olağanüstü dardır, zira orman ve madenlerle dolu olan dağlar bunun hemen üstündedir ve kıyının çoğu işlenmiştir. Böylece madencilere hayatlarını kazanabilmeleri için madenler ve denizle meşgul olanların da geçimlerini sağlayabilmeleri için balıkçılık, özellikle palamut ve yunus avı kalır; çünkü yunuslar, aynı cinsten olan kordyles, ton ve palamutu kovalar ve bu suretle sadece bunları yiyerek şişmanlamakla kalmazlar, fakat karaya yaklaşmakta çok istekli olduklarından da kolay yakalanırlar. Bunlar olta ile tutulan yunusların yağlarını her maksat için kullanan yegâne insanlardır". ${ }^{131}$
\end{abstract}

Strabon bu arada Alybe ile Khalybe isimlerinin aynı olduğu ve zaman içersinde değiştiğini ifade etmektedir; "Özellikle barbar kavimler arasında isimlerin çok değiştiği zamanlarda, Alybe'nin Khalybe olarak değiştiği kabul edilmezse, şimdi Khaldai isminin Khalybe'den çıktığını kanıtlamak da olanaksiz olur". ${ }^{132}$

Herodotos, Kyros'un ele geçirdiği halklardan bahsederken Khalyb'lerden de bahsetmektedir;

"Günler günlere katıldı, Halys ırmağının beri yakasındaki ulusların, Kilikia ve Lykia'dan gayri hepsi boyun eğmiş, Kroisos'un egemenliğini tanımışlardı; bunlar: Lydia'lılar, Phrygia'lılar, Mysia'lılar, Khalybler, Mariandyn'ler, Paphlagonia'lllar, Thraklar, Thyn'ler, Bithynia'lllar ve Kar'lar, İon'lar Dor'lar Aiol'lar, Pomphylia'lllardı". ${ }^{133}$

Khalyb'ler hakkında Ksenephon'da da önemli bilgileri bulmaktayı. Ksenephon'un anlatımlarından onların hem yaşadıkları coğrafya hem yaşam biçimleri hem

\footnotetext{
${ }^{130}$ Burney-Lang, 1971: 129; Bryer-Winfield, 1985: 300 vd.; Çiğdem, 2006: 106.

${ }^{131}$ Strab. XII, III, 19.

${ }^{132}$ Strab. XII, III, 20-28.

${ }^{133}$ Hdt. I, 28.
} 
de kişilikleri hakkında ayrıntılı bilgiler edinmekteyiz;

Buradan sonra iki günde on parasang giderek dağların ovaya inmek için aşılacak yerinde Khalyb'ler Taokhlar ve Phasian'larla karşılaştılar". ${ }^{134}$ "Bundan sonra Hellen'ler Khalyb'ler memleketinde yedi günde on beş parasang ilerlediler. Bunlar memleketlerinden geçtikleri bütün kavimlerin en cengâverleri idiler. Ve dövüşten çekinmiyorlardı. Zırhları ketenden idi ve karınlarına kadar iniyordu, zırhlarının etekleri sıkı bükülmüş iplerden yapılmıştır. Dizlik ve mi ğfer taşıyorlardı. Kemerlerinden hemen hemen Lakonia kılıçları büyüklüğünde bir harp bıçağı sokulu idi. Alt edebildikleri bütün düşmanlarını bununla öldürüyorlardı. Onların kafalarını kesiyor ve çekilirken beraber götürüyorlar, düşmanları kendilerini görebilir ise şarkı söylüyor dans ediyorlardı. Takriben on beş kol uzunluğunda ve tek uçlu birer mızrakları vardı. Kasabalarında bekliyorlar ve Hellenler geçince hemen arkalarına düşüyor, peşi sıra dövüşüyorlardı. Müstahkem yerlerde oturuyorlardı, bütün zahirelerini de buralara taşımışlardı. Bu yüzden Hellen'ler yiyecek elde etme imkânı bulamadılar ve Taokh'lardan yağma ettikleri hayvanları keserek yiyecek temin edebildiler". ${ }^{135}$ "Bu memleketin dost ve düşman k1sımlarını Hellen'ler sekiz günlük yürüyüşle geçtiler ve Khalyb'lerin memleketine vard1lar. Bunlar kalabalık değillerdi ve Mossynoik'lerin tabii idiler. Geçim vasıtaları da en ziyade demir madenlerinde çalışmaktı. ${ }^{136}$

Strabon ${ }^{137}$ Khalybe/Khaldia'yı, geniş bir şekilde tartışarak, Sinope ve Amisos'un doğusunda, Herodotos Halys/Kızıl Irmak'ın doğusunda, ${ }^{138}$ Ksenophon ise yukarda görüldüğü gibi onları Erzurum'un kuzeyinde göstermektedir. Hem Strabon hem Ksenophon'un Khalybe/Khaldia tanımlamalarında, bu insanların topraklarının sınırlarının, Kuzeydoğu Anadolu'nun iç kısımlarından denize kadar ulaştığını ve bu corafayda yaşayan bu iki unsurun günümüzde

\footnotetext{
${ }^{134}$ Ksen. Anab. IV, VI,5

135 Ksen. Anab. IV, VII, 15-17.

${ }^{136}$ Ksen. Anab. V, V, 1.

${ }^{137}$ Strab. XII, III, 28; XIV, V, 24; Hdt. I, 28; Ksen. Anab. IV, VI, 5 .

${ }^{138}$ Herodotos burada Halys'ın beri yakası deyip daha çok Kızıl Irmak'ın batısındaki halkları sıralamıştır,
}

olduğu gibi, bölgenin ekolojik yapısı ile doğru orantılı olarak geçimlerini sağladıklarını özellikle demircilikle uğraştıklarını çok açık bir şekilde göstermektedirler.

Bununla birlikte Khalybes'lerin Thermedon Irmağı etrafında yaşadıkları ve İskit kökenli oldukları, Areos'un oğlu Khalybos'un soyundan geldikleri de yine antik kaynaklarda ifade edilmektedir. ${ }^{139}$ Peake, ${ }^{140}$ Hitit dil bilimci Archibald Henry Sayce'ın, “'Alybe' ya da 'Khalybes' kelimelerinin, Hititçe Khaly-wa (Halys Ülkesi) kelimesine karşıllık gelebileceği” önerisini çalışmasına taşıyarak Halys Irmağ 1 üzerinde yaşayan Khalybes'lerin "Khaly-wa" adı ile MÖ XIV. yüzyll Hitit metinlerinde var olabileceğini belirtmektedir. P'yankov ${ }^{141}$ ise da (K)halybe-(K)haldia bağlantısına dikkat çekerek "Khalybe" adının zamanla "Khaldia”ya dönüşdüğünü ve bu coğrafyanın s1nırlarının Pharnakeia'nın yukarı kesimlerinden Armenia Minor'a kadar uzanan, gümüş ve demir başta olmak üzere oldukça zengin maden kaynaklarına sahip dağlık bir bölge olarak tanımlamaktadır. Dolayısiyla Strabon zamanında "Khaldia" olarak adlandırlan Khalybes'lerin yaşadığ 1 coğrafya, günümüzde Gümüşhane ve Bayburt illerini içine alacak bir şekilde belirlenmiştir. ${ }^{142}$

Konu ile ilgili benzer bir değelendirme yapain Sinclair ${ }^{143}$ Khaldia isminin, Karadeniz'de oluşturulan Grek kolonizasyonu esnasında, Grekler tarafindan burada bulunan Grek orijinli olmayan yerli halkı tanımlamada kullanılmış olabileceğini, çünkü Pre-Klasik, Klasik ve Antik dönemlerde bu bölgenin Khaldia olarak adland1rıldığını gösteren bir kanıtın olmadığını ve Urartu tanrısı Haldi isminden yola çıkılarak Urartu ile bölge arasında da bir bağlantının kurulamayacağını savunmaktadır.

yalnız Erhat dizinde Khalybe'yi Kızılırmak'ın doğusuna lokalize etmiştir. Hdt. I. 28

${ }^{139}$ Rhod. Apol. Arg. II. 354.

140 Peake, 1933: 644.

${ }^{141}$ P'yankov, 2002: 330

${ }^{142}$ Kanu hakkında daha geniş bilgi ve tartışma için bk.

Demir, 2009: $67 \mathrm{vd}$.

${ }^{143}$ Sinclair, 1989: 125 . 
Bu konuda Adontz ${ }^{144}$ da benzer bir görüşle "Haldi" kelimesinin "barbar" anlaminda kullanılmış ise bununla bölgede yaşayan İskitlerin tanımlanmış olabileceğini ileri sürmektedir.

Bütün bu bilgilerle bölgeye, Pers-Roma dönemlerinde verilen Khaldia/Khalybe ismi ile Doğu Roma döneminde verilen Khaldia $^{145}$ ismi arasında ne gibi bir bağlantının olduğu ve özellikle etnik açıdan, Urartu baştanrısına dayandırılan HaldiKhalybe/Khaldia arasında bir ilişkinin olup olmadığını söylemek güçtür. Eğer bölgede, hâlâ kullanılmakta olan Haldi ismi ile geçmiş dönemlerde geçen isimler arasında bir bağlantı kurma zorunluluk ise bu bağlantıyı Uraratu kaynaklarında geçen ve Tarhan ${ }^{146}$ tarafından Karadeniz'e lokalize edilen Halitulularla yapmamız daha olası görülmektedir. Özellikle madencilikle uğraştıklarını bildiğimiz Halitu ülkesi halkı (Gümüş Ülkesi'nin adamları)'nın ${ }^{147}$ madencilik gelenekleri ile beraber isimleri de kendilerinden sonra gelenlerin hafızalarında yaşamış olmalıdır. Burada, Halitu ismini Urartu $^{148}$ kaynaklarında gördüğümüzü belirtmeliyiz. Onların kendilerini nasıl tanımladıkları ile ilgili tarihsel bulgulardan şu an için yoksun durumdayız. Yine de kanımızca, Halitu-Khaldia-Haldi isim benzerliği, bölgede hâlâ yaşmakta olan Haldi isminin açıklanmasında, göz önünde bulundurulması gereken güçlü alternatiflerden biri olmalıdır.

\section{Sonuç}

Kuzeydoğu Anadolu'da bölgesi içinde yer alan Bayburt ili, konumu itibarıyla Karadeniz kıyılarını iç kesimlere bağlayan bir özelliğe sahiptir. Bulunduğu stratejik konum itibarıyla Hellenistik ve Roma dönemlerinde yörenin sınır bölgesi olarak kullanıldığı özellikle Satala askerî karargâhının varlığından da anlaşılmaktadır. Yapılan yüzey araştırmaları sonucunda yörenin farklı bölgelerinde tespit edilen Hellenistik-Roma seramikleri, yörenin bu dönemdeki iskân yoğunluğuna işaret etmektedir.

2008 yılından itibaren Bayburt ve çevresinde gerçekleştirdiğimiz yüzey araştırmalarında, bölgede Roma Dönemi'ne ait askerî ve sivil yerleşim alanlarının yeterli oranda olduğu tespit edilmiştir. Antik yazılı kaynaklar ve bunları destekleyen arkeolojik verilerden Bayburt ve Gümüşhane çevresinin özellikle Geç Hellenistik dönemden itibaren stratejik olarak oldukça önemli bir yer hâline geldiği görülmektedir. Roma-Parth daha sonra Doğu RomaSasani mücadelelerinin merkezinde yer alan Bayburt ve çevresi bu güçlerin bölgede kendi lehlerine oluşturmaya çalıştıkları tampon bölgenin önemli bir parçası olmuştur. Bununla birlikte mevcut kaynaklar ve araştırmalar doğrultusunda, MÖ 2. yüzyıldan MS 10. yüzyıla kadar ele aldığımız Bayburt ve çevresinin Eski Çă̆ Tarihi ile ilgili yukarıda değindiğimiz sorunların, bölgede yapilacak arkeolojik kazılar sonucunda ele geçecek yeni bulgularla daha da belirgin bir şekilde çözümlenebileceği tartışılmaz bir gerçektir.

\section{KAYNAKÇA}

ADAMS, W. L. (2006), “The Hellenistic Kingdoms", Glenn R. Bugh (Ed.), The Hellenistic World, içinde (28-51), London and New York: Cambridge University Press.

ADCOCK, F.E. (1971), “The Civil War" The Roman Republic, CAH, IX, 638-690.

ADONTZ, N. (1946), Historie d'Armenie Les Origines du X. Siecle au VI (Av.J. C.), Paris.

, (1970), Armenia in the Period of Justinian The Political Conditions Based on the Naxarar System, Translated With Partial Revisions A Bibliographical Note and Appendices By N. G.

147 Belli, 1991: 22

${ }^{148}$ Payne, 2006: 282-283.

\footnotetext{
44 Adontz, 1964: 309

${ }^{145}$ Ramsay, 1960: 305-349

${ }^{146}$ Tarhan, 1986: 299.
} 
ANDERSON, J.G.C. (1922), “Pompey’s Campaign against Mithradates”, JRS, 12, 99105.

ANTONINE Itinerary, http://assests.cambridge.org/052130/1998/in-

dex/0521301998_index.pdf 06.09.2006.

ARSLAN, M. (2006), "PONTOS'TAN KARADENIZ'E: Bir Adlandırmanın Ardındaki Önyargılar, Varsayımlar ve Gerçekler”, Olbia, XIV, 71-88.

(2007), Roma'nın Büyük Düşmanı Mithrdates VI Eupator, İstanbul.

ARTHUR, J.-R. Munro (1901), "Roads in Pontos, Royal and Roman”, JHS, 21, 52-66.

BALL, W. (2002), Rome in the East The Transformation of an Empire, London and New York.

BALLESTEROS-Pastor, L. (2008), "Cappadocia and Pontus, Client Kingdoms of the Roman Republic from the Peace of Apamea to the Beginning of the Mithridatic Wars (188-89 B.C.)", A. Coşkun (Ed.), Freundschaft und Gefolgschaft in Den Auswärtigen Beziehungen der Römer (2. Jahrhundert V.chr.- 1.jahrhundert N.chr.), içinde (4563), Frankfurt am Main, Alemania: Peter Lang.

BAYDUR, N. (1982), Imparator Ilianus, İstanbul.

BELLI, O. (1991), “Ore Deposits and Mining in Eastern Anatolia in the Urartian Period: Silver, Copper and Iron”, R. Merhav (Ed.), Urartu A Metalworking Center in the Frist Millennium B.C.E. (Ed. By), içinde (16-41), Jerusalem.

BENNETT, Julian (2005), Trajan Optimus Princeps: A Life and Times, London and New York: Routledge.

BIRLEY, A. R. (2008), "Hadrian to the Antonines”, K. A. Bowman ve diğerleri (Eds.), The High Empire A.D. 70-192, CAH, XI, içinde (132-194), Oxford and New York: Cambridge University Press/Cambridge Histories Online.

(2012a), "Cassius Dio and Historia Augusta”, Marcel van Ackeren (Ed.), A
Companion to Marcus Aurelius, içinde (1328), Oxford and New York: Blackwell Publishing.

, (2012b), “The Wars Revolt”, Marcel van Ackeren (Ed.), A Companion to Marcus Aurelius, içinde (13-28), Oxford and New York: Blackwell Publishing.

BIVAR, A. H. D. (1983), "The Political History of Iran under the Arsacid", Ehsan Yarshater (Ed.), The Seleucid, Parthian and Sasanian Period", The Cambridge History of Iran, III(1), içinde (21-99), Cambridge, New York, Melbourne, Madrid, Cape Town, Singapore, Sao Paulo: Cambridge University Press.

BOATWRIGHT, M. T. (2000), Hadrian and the Cities of the Roman Empire, New Jersey: Princeton University Press.

BOKŞÇANIN, A. G. (1960-1966), Parfiya $i$ Rim, Vozniknovenie sistema, politiçeskogo dualizma $v$ peredney Azii, Çast' I-II, Moskva: İzdatel'stvo Moskovskogo Universiteta.

BOATWRIGHT, M. T. (2008), "Hadrian”, A. A. Barrett (Ed.), Lives of the Caesars, içinde (155-180), Oxford and New York: Blackwell Publishing.

BOSCH, M. E. (1943), Helenizim Tarihinin Anahatları II. Kisim Roma Imparatorluğu'na Katıldıkalrı Tarihe Kadar Helenizm Devletleri, (Çev. S. Atlan), İstanbul.

BOSWORTH, A. B. (1976), "Vespasian's Reorganization of the North-East Frontier" Antichthon, 10, 63-78.

, (1977), "Arrian and the Alani" Harvard Studies in Classical Philology, 81, 217-255.

(1983), "Arrian at the Caspian Gates: A Study in the Methodology" $C Q$, 33/1, 265-267.

BRAUND, D. (1994), Georgia in Antiquity: A History of Colchis and Transcaucasia Iberia 550 BC- $A D$ 562, Oxford: Clarendon Press.

BRYER, A. (1980), The Empire Trebizond and Pontos, London. 
(1988), "The Question of Byzantine Mines in Pontos: Chalybian Iron, Chaldian Silver, Koloneian Alum and the Mummy of Cheriana", Settlement in Anatolia and Caucassus 800-1900, London.

BRYER, A.-D. Winfield (1985), The Byzantine Monuments and Topography of the Pontos I, (Dumbarton Oaks Studies 20), Washington: Dumbarton Oaks.

CAMPBELL, B. (1993), "War and Diplomacy: Rome and Parthia, 31 BC-AD 235", John Rich and Graham Shipley (Eds.), War and Society in the Roman World, LeicesterNottingham Studies in Ancient Society Volume 5, içinde (213-240), London and New York: Routledge.

CARRINGTON, Peter (1976), The Distribution and History of Elements of the Native Culture of Roman Phrygia with Reference to their Ethnic Origin, Yayınlanmamış Doktora Tezi, University of Newcastle.

CHAHIN, M. (1987), The Kingdom of Armenia, New York: Dorset Press.

CHAUMONT, M. L. (1976), “L’Arménie entre Rome et l'Iran I. De l'avènement d'Auguste a l'àvènemet de Diocletion", $A N R W$, II.9.1, 71-194.

CHRISTENSEN, A. (1936), L'Iran Les Sassanides, Copenhagune.

CORNELL, T.-J. Matthews (1988), Roma Dünyasl, İletişim Atlaslı Büyük Uygarlıklar Ansiklopedisi, V, (Çev. Ş. Karadeniz), İstanbul.

CUMONT, F. (1923), "L'Annexion du Pont Polémoniaque et de la Petite Arménie", W. H. Buckler-W. M. Calder (Eds.), Anatolian Studies Presented to Sir William Mitchell Ramsay, içinde (109-119), Manchester.

CUMONT, F.-E. Cumont (1906), Voyage d'exploration archeologique dans la Pont et la Petit Armenie. Studia Pontica 2, Brussels.

CURZON, G. N. (1966), Persia and the Persian Question II, London and Edinburgh.

CZEGLÉDY, K. (1999), Turan Kavimleri'nin Göçü, (Çev. G. Karaağaç), İstanbul.
Ç̇̇̆GEM, Süleyman (2006), "Urartu Krallığı'nın Doğu Karadeniz İlişkilerinde Diauehi Ülkesinin Rolü” Atatürk Üniversitesi Sosyal Bilimler Enstitüsü Dergisi, 7/1, 95112.

(2011), "Roma-Parth İlişkilerinde Elegeia/Erzurum ve Çevresi” Atatürk Üniversitesi Edebiyat Fakültesi Edebiyat Sosyal Bilimler Dergisi, 11/46, 97-118.

(2013), "Bayburt/Aydıntepe Yüzey Araştırması Işı ğında Bölgenin Eskiçağ Tarihinin Değerlendirilmesi” A.̈̈. Güzel Snatlar Enstitü Müdürlüğü Güzel Sanatlar Enstitüsü Dergisi, 30, 65-81.

Çí̆̆DEM, S.-O. Emir (2017), "Bayburt Kalesi'nin Prehistoriası ve Eski Çağı Üzerine Genel Bir Değerlendirme", Kaleli Kentler ve Bayburt Kalesi Kongresi, içinde (21-35), İstanbul.

Çİ̆GEM S.-H. Yurttaş-H. Özkan (2011), "2009 Yılı Bayburt Yüzey Araştırması". 28. Araştırma Sonuçları Toplantısı 1, (24-28 Mayıs 2010 İstanbul), içinde (155-174), Ankara.

ÇİĞDEM S.-H. Yurttaş-H. Özkan (2014), "2012 Bayburt Yüzey Araştırması", 31. AST 2 (27-31 Mayıs 2013 Muğla), içinde (1930), Muğla.

ÇíĞDEM, S.-H.Yurttaş-H. Özkan (2016), "2014 Bayburt Yüzey Araştırması" 33. AST 1 (11-15 Mayıs 2015 Erzurum), içinde (119136), Ankara.

ÇİĞDEM, S.-H. Yurttaş-H. Özkan (2017), "2015 Bayburt Yüzey Araştırması Raporu" 34. AST 2 (23 -27 Mayls 2016 Edirne), içinde (161-174), Edirne.

DEBEVOISE, N. C. (1968), A Political History of Parthia, Chicago.

DEMİRCIOĞLU, H. (1987), Roma Tarihi I/1 Cumhuriyet Menşelerden Akdeniz Havzasinda Hâkimiyet Kurulmasına Kadar, Ankara.

DMITRIEV, S. (2006), "Cappadocian Dynastic Rearrangements on the Eve of the First Mithridatic War", Historia, 55 (3), 285-297. 
DODGEN, M.H.-N.C.Lieu (1991), The Roman Eastern Frontier and the Persian Wars ( $A D$ 226-363) A Documentary History, London-New York.

DRINKWATER, J. (2008), "Maximinus to Diocletion and the Crisis", A. K. Bowman ve diğerleri (Eds.), The Crisis of Empire, $\mathrm{CHA}$, XII, second Edition içinde (28-66), Cambridge, New York, Melbourne, Madrid, Cape Town, Singapore, Sao Paulo.

DEMIR, M. (2009), "Antik Dönemde Bir Doğu Karadeniz Kavmi: Khalybler”, Giresun ve Doğu Karadeniz Sosyal Bilimler Sempozyumu 9-11 Ekim 2008, Cilt. 1, içinde (67-85), Giresun.

EMİ, Osman (2011), Prehistorik Dönemden Roma Dönemine Kadar Trabzon ve Çevresi, Trabzon.

, (2014), Hellenistik ve Roma Dönemlerinde Pontos (MÖ IV. Yy. - MS III. yy.), Yayınlanmamış Doktora Tezi, Trabzon.

ERRINGTON, R. M. (1989), "Rome Against Philip and Antiochus", Ed. A.E. Aiston ve diğerleri, $C A H$, VIII, 224-275.

(1972), The Dawn of Empire: Rome's Rise to World Power, New York.

FARROKH, K. (2007), Shadows in the Desert: Ancient Persia at War, Oxford and New York.

FOSS, C. (1975), "The Persians in Asia Minor and the End Antiquity", EHR, 90/357, 721-747.

FRYE, R. N. (1962), The Heritage of Persia, London.

München.

(1984), The History of Iran,

GIBBON, E. (1987-1988), Roma Imparatorluğu'nun Gerileyiş ve Çöküş Tarihi 1-3, (Çev. A. Baltacıgil), İstanbul.

GILMARTIN, K. (1973), “Corbulo's Campaigns in the East: An Analysis of the Tacitus' Account”, Historia, V(4), 583-626.
GOLDSWORTHY, A. K. (2014), Caesar, (Çev. E. Kurtluoğlu), İstanbul: Türkiye İş Bankası Kültür Yayınları.

GRIFFIN, M. T. (2008), "Nerva to Hadrian”, A. K. Bowman ve diğerleri (Eds.), The High Empire A.D. 70-192, CAH, XI, içinde (84-131), Oxford and New York: Cambridge University Press/Cambridge Histories Online.

HILMAN, T. P. (1993), "When Did Lucullus Retire?”, Historia, 42 (2), 211-228.

HIND, J.G. F. (1992), "Mithridates", The Last Age of The Roman Republic, 146-43 B.C., CAH, IX, içinde (129-161), J. A. Crook ve diğerleri (Eds.), New York: Cambridge Histories Online/Cambridge University Press.

HONIGMANN, E. (1970), Bizans Devleti'nin Doğu Stnırı, Grekçe Arabça, Süryanice kaynaklara göre 363'den 1071'e kadar, (Tercüme eden F.Işıltan), İstanbul.

JONES, A. H. M. (1969), The Cities of the Eastern Roman Provinces, Oxford.

ISAAC, B. (1990), The Limits of Empire. The Roman Army in the East. Oxford.

KAYA, M. A. (2004), "Romalilar, Parthlar ve Armenia Krallığı (İ.Ö. 96-İ.S. 4)”, Tarih Incelemeleri Dergisi, XIX/1, 73-86.

(2005a), "Roma Lejyonerleri ve Anadolu”, Tarih Araştırmaları, XXII/36, 87-96.

(2005b), “Anadolu'da Roma Eyaletleri: Sinırlar ve Roma Yönetimi”, Tarih Araştırmaları Dergisi, 38, 11-30.

, (2006), "Roma İmparatoru Septimus Severus Döneminde Anadolu”, Tarih Araştırmaları Degisi, 39, 27-48.

KHORENATS'I, M. (1980), History of the Armenians, (Translation and Commentary on the Literary Sources by R.W. Thomson), London.

LIGHTFOOT, C. S. (1990), “Trajan's Parthian War and the Fourth-Century Perspective", JRS, 80, 115-126. 
LIOYD, S. (1997), Türkiye'nin Tarihi Bir Gezginin Gözüyle Anadolu Uygarlıkları, (Çev. E. Varinlioğlu), Ankara.

LONGDEN, R. P. (1931), "Notes on the Parthian Campaigns of Trajan”, JRS, 21, 1-35.

MADSEN, J. M. (2009), "The Ambitions of Mithridates VI: Hellenistic Kingship and Modern Interpretations”, Jakop Munk Højte (Eds.), Mithradates VI and the Pontic Kingdom, (Black Sea Studies 9, The Danish National Research Foundation's Centre for Black Sea Studies), içinde (191-202), Denmark: Aarhurs University Press.

MAGIE, David (1950), Roman Rule in Asia Minor to the End of the Third Century After Christ I-II, Princeton, New Jersey.

(2001, 2003), Anadolu'da Romalılar I-II-III, (Çev. N. Başgelen-Ö. Çapar), İstanbul.

MANANDYAN, Ya. A. (2007), Tigranes II and Rome: A New Interpretattion Based on Primary Sources, Annotated Translation and Introduction by G. A. Bournotian, California: Mazda Publishers.

MANSEL, Arif Müfit (1998), Ege ve Yunan Tarihi, Ankara.

MAYOR, A. (2013), Mithradates, Zehirlerin Kralı: Roma'nın En Acımasız Düşmanının Hayatı ve Efsanesi, (Çev. Gürkan Ergin), İstanbul.

MCLYNN, F. (2009), Marcus Aurelius: A Life, Cambridge.

MERRILL, E. T. ,81901), “Some Observations on the Arch of Trajan Beneventum", TPAPA, 32, 43-63.

MITCHEL, S. (1993), Anatolia Land, Man, Gods in Asia Minor I-II, Oxford.

MITCHELL, T. C. (1997), "Achaemenid History and the Book of Daniel”, J. Curtis (Ed.), Mesopotamia and Iran in Persian Period Conquest and Imperialism 539-331 BC, Proceedings of a Seminar in memory of $\mathrm{Vi-}$ ladimir G. Lukonin, içinde (68-78), London.
MITFORD, T. B. (1974), "Some Incriptions from the Cappadocian Lines", JRS, 64, 160175 .

(1980), "Cappadocia and Armenia Minor: Historical Setting of the Limes", $A N R W$, II.7.2, 1170-1228.

(2000), "Thalatta, Thalatta: Xenophon's view of the Black Sea", $A S, 50$, 127-131.

(2018), East of Asia Minor Rome's Hidden Frontier I-II, Oxford.

MOLEV, E. A. (1995), Vlastitel' Ponta: Monografiya, İzd. Nijniy Novgorod: Nijegorodskiy Universitet.

MOLEV, E. A. (2009), "Bosporos under the Rule of Mithridates VI Eupator", Jakob Munk Højte (Ed.), Mithridates VI and the Pontic Kingdom, içinde (321-328), Denmark: Aarhus University Press.

MOMMSEN, T. (1958), The Rome History The Conquest of Carthage to the end of the Republic, (a new edittion by D.A.SaundersJ.H.Collins), Clinton, Massachutes. (2005), A History of Roman under the Emperors, Based on the Lecture Notes of Sebastian and Paul Hensel, 18826 , German edition by Barbara and Alexander Demandt, English translation by Clare Krojzl, (Ed.), with the addition of a new chapter, by Thomas Wiedemann, London and New York: Routledge.

OLBRYCHT, M. J. (2001), “Die Aorser, die Oberen Aorser und die Siraker bei Strabon. Zur Geschichte und Eigenart der Völker im nordostpontischen und nordkaukasischen Raum im 2.-1. Jh.v. Chr.”, Klio, 83, 425450.

(2009), “Mithridates VI Eupator and Iran", Jakob Munk Højte (Ed.), Mithradates VI and the Pontic Kingdom, (Black Sea Studies 9, The Danish National Research Foundation's Centre for Black Sea Studies), içinde (163-190), Denmark: Aarhur University Press. 
OLSHAUSEN, E. (1980), "Pontos und Roma (63 v. Chr.-64 n. Chr.)", ANRW, II.7.2, 903912.

ORMERROD, H.A. (1971), “Lucullus' Operations in the Lycus Valley", The Roman Republic 133-44 B.C. CAH, IX, 897-898.

ORMEROD, H. A.-M.Cary (1971), "Rome and The East", The Roman Repulic 133-44 B.C. CAH, IX, 350-395.

OSTROGORSKY, G. (1986), Bizans Devleti Tarihi, (Çev. F. Işıltan), Ankara.

ÖZSAİT, M. (1982a), “Anadolu'da Helenistik Dönem”, Anadolu Uygarlıkları 2, Görsel Anadolu Tarihi Ansiklopedisi, içinde (333378), İstanbul.

(1982b), “Anadolu'da Roma Egemenliği”, Anadolu Uygarlıkları 2, Görsel Anadolu Tarihi Ansiklopedisi, içinde (379416), İstanbul.

(1985), Helenistik ve Roma Devrinde Pisidya Tarihi, İstanbul. (2000), “İlkçağ Tarihinde Trabzon ve Çevresi” Trabzon Tarihi Sempozyum Bildirileri (6-8 Kasım 1998 Trabzon), içinde (35-46), Trabzon.

PAYNE, R. (1970), Ancient Rome, New York.

PEAKE, H. (1933), The Origin and Early Spread of Ironworking", Geographical Review, 23/4, 639-652 .

P’YANKOV, I. V. (2002), “Galizonı - Halib1 - Moshi (K voprosu o tsirkumpontiyskoy kaste metallurgov kontsa II- I tıs. do n.é.)", ZVORAO, N.S., I (XXVI), 324-342.

PELHAM, H.F. (1896), "Arrian as Legate of Cappadocia”, EHR, 11/44, 625-640.

RAMSEY, W. M. (1960), Anadolu'nun Tarihi Coğrafyası, (Çev. M. Pektaş), İstanbul.

ROSTOVTZEFF, M.-Ormerod, H. A. (1932), "Pontos and Neighbors: The First Mithridatic Wars”, S. A. Cook ve diğerleri (Eds.), The Roman Republic 133-44 B.C., CAH, IX, içinde (211-26o), London: Cambridge University Press.
SAGONA, A.-C. Sagona 2004: "An Archaeological Survey of the Bayburt Province" Archaeology at the North-East Anatolian Frontier, I. An Historical Geography and a Field Survey of the Bayburt Province, Louvain - Paris - Dudley, MA: Peeters (Ancient Near Eastern Studies Supplement 14).

SAPRYKIN, S. Ju (2003), "The Policy of Mithridates Eupator and the North Coast of the Black Sea", Paper delivered at the University of Aarhus, 1-4.

SARIKAYA, S. (2013), “Arrianus'un 'İskender'den Sonraki Olaylar' Adlı Eseri/To

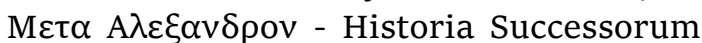
Alexandri", Cedrus, I, 229-245.

SHERWIN-White, A. N. (1984), Roman Foreign Policy in the East, 168 B.C. to A.D. 1, Norman: University of Oklahoma Press.

SINCLAIR, T. A. (1989), Eastern Turkey An Architectural and Archaeological Survey Vol. II, London.

SÖKMEN, E. (2006), “Komana Pontika ve Zela: Pontos Bölgesi’ndeki Tapınak Devletleri”, D.B. Erciyas-E.Koparal (Yayına Haz.), Karadeniz Araştırmaları Sempozyum Bildirileri (16-17 Nisan 2004, Ankara), içinde (119-128), İstanbul.

STARK, F. (1966), Rome on the Euphrates: The Story a Frontier, London: John Murray.

SULliVAN, D. R. (1980), Some Dynastic Answers to the Armenian Question: A Study in East Anatolian Prosopography, Yayınlanmamış Doktora Tezi, University of California.

SYME, R. (1977), “The Enigmatic Sospes”, JRS, 67, 38-49.

(1982), "The Career of Arrian" Harvard Studies in Classical Philology, 86, 181-211.

(1988), "Journeys of Hadrian", $Z P E, 73,159-170$

TARHAN, M. T. (1986), “Urartu Devleti'nin Yapısal Karakteri”, IX. TTkong. I,(Ankara 21-21 Eylül 1981), içinde (285-301), Ankara. 
TARN, W. W. (1971), “ Prathia”, The Roman Republic 133-44 B.C. CAH, IX, 574-613.

USLU, G. A. (1991), “Gümüşhane'nin Tarihçesi ve Turistik Değerleri”, Geçmişte ve Günümüzde Gümüşhane (13-17 Haziran199o), içinde (141-153), Anakara.

VAN WIJLICK, H. A. M. (2013), Rome and the Near Eastern Kingdoms and Principalities, 44-31 BC: A Study of Political Relations during Civil War, Yayınlanmamış Doktora Tezi, Durham University.

WINFIELD, D. (1977), "The Northern Routes across Anatolia”, AS, 27, 151-166.

YARLIGAŞ, Oğuz (2016), "Legio XV Apollinaris'in Doğu'daki Görevleri ve Satala'ya Konuşlandırıldığ 1 Tarih Üzerine”, Eskiçağ Yazıları,10, 127-158.

YILDIZ, H. D. (1982), "Bizans Tarihi", Anadolu Uygarlıkları 3 Görsel Anadolu Tarihi Ansiklopedisi, içinde (488-565), İstanbul.

YORKE, V. W. (1896), "A Journey in the Valley of the Upper Euphrates", G J,8/5, 453-472. (1898), "Inscriptions from Eastern Asia Minor", JHS, 18, 306-327.

ZEHİROĞLU, A. M. (2000), Antik Çağlarda Doğu Karadeniz, İstanbul. 


\section{EKLER}

Resim 1: Saruhan Kalesi

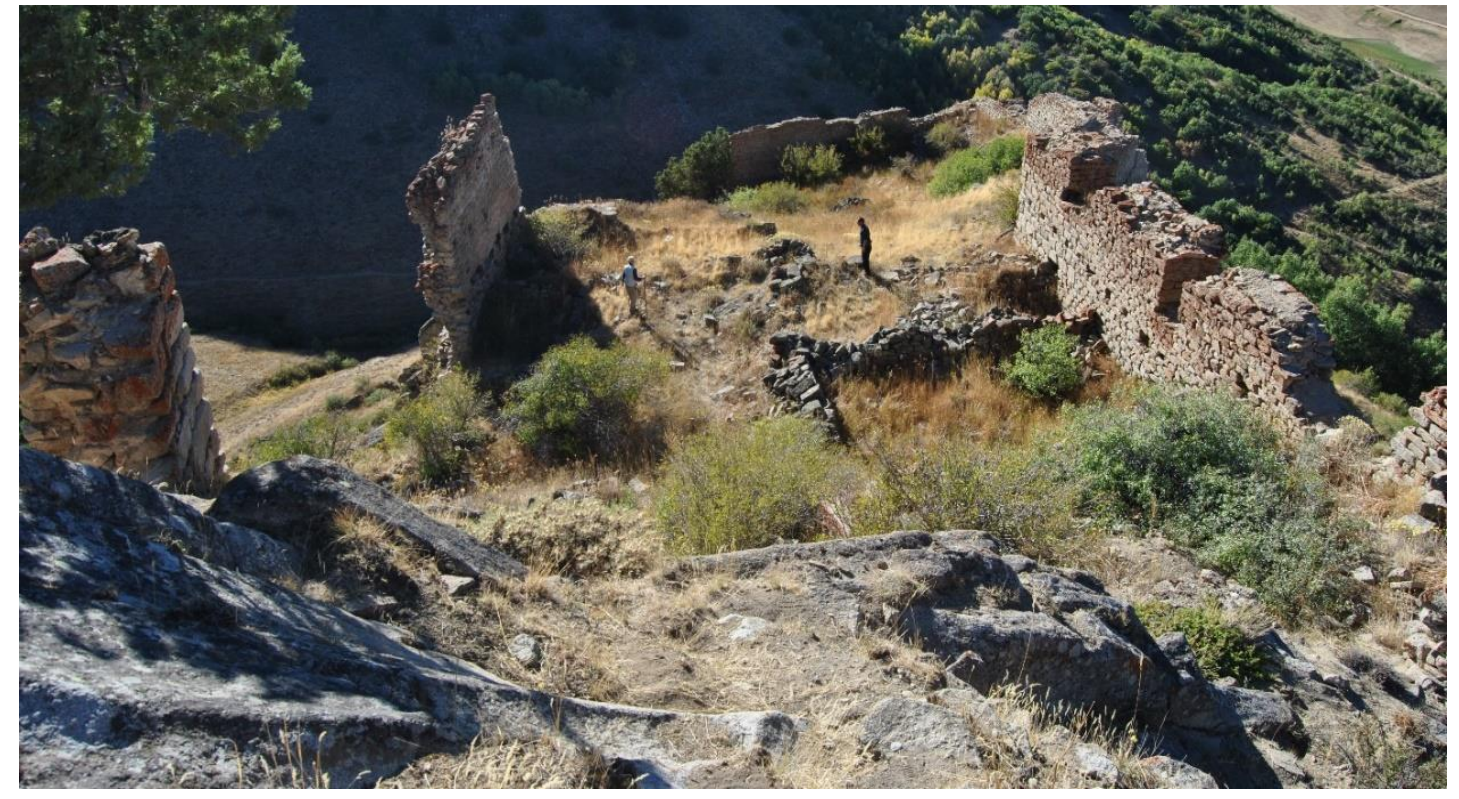

Resim 2: Yeniköy, Alavlu Düzü

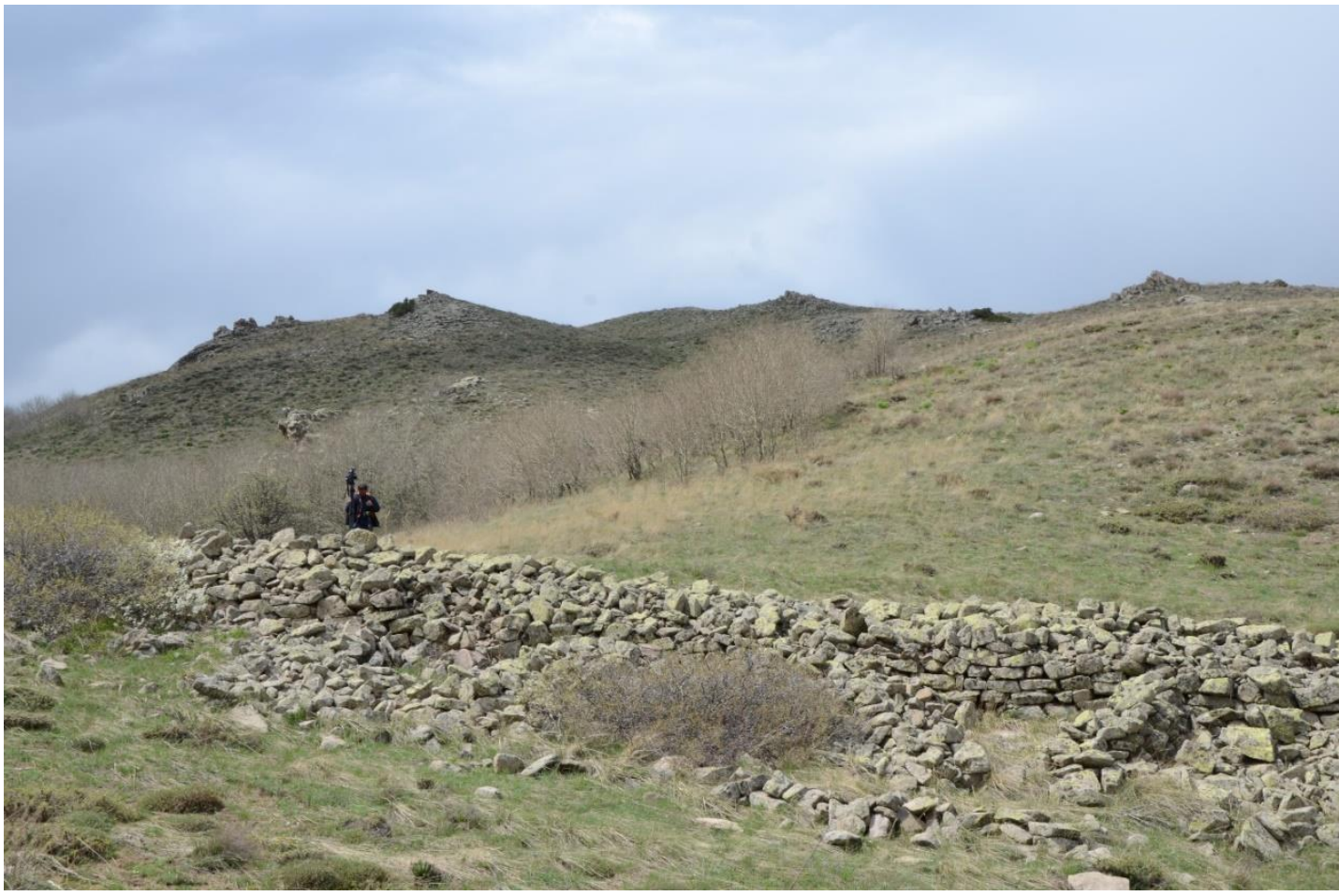




\section{Resim 3: Bayburt Kalesi}

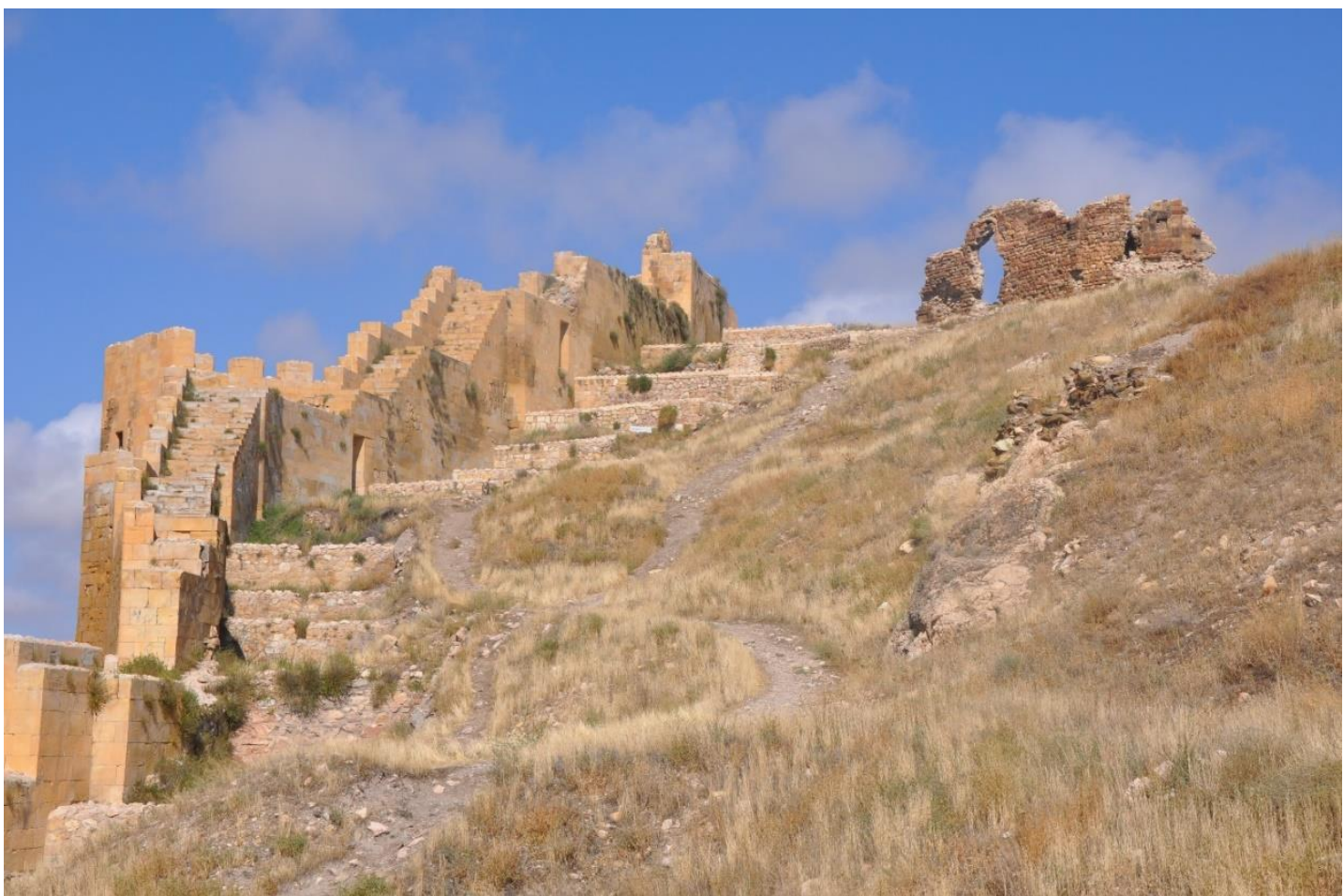

Resim 4: Yazyurdu Köyü, Kale-Gözetleme Kulesi

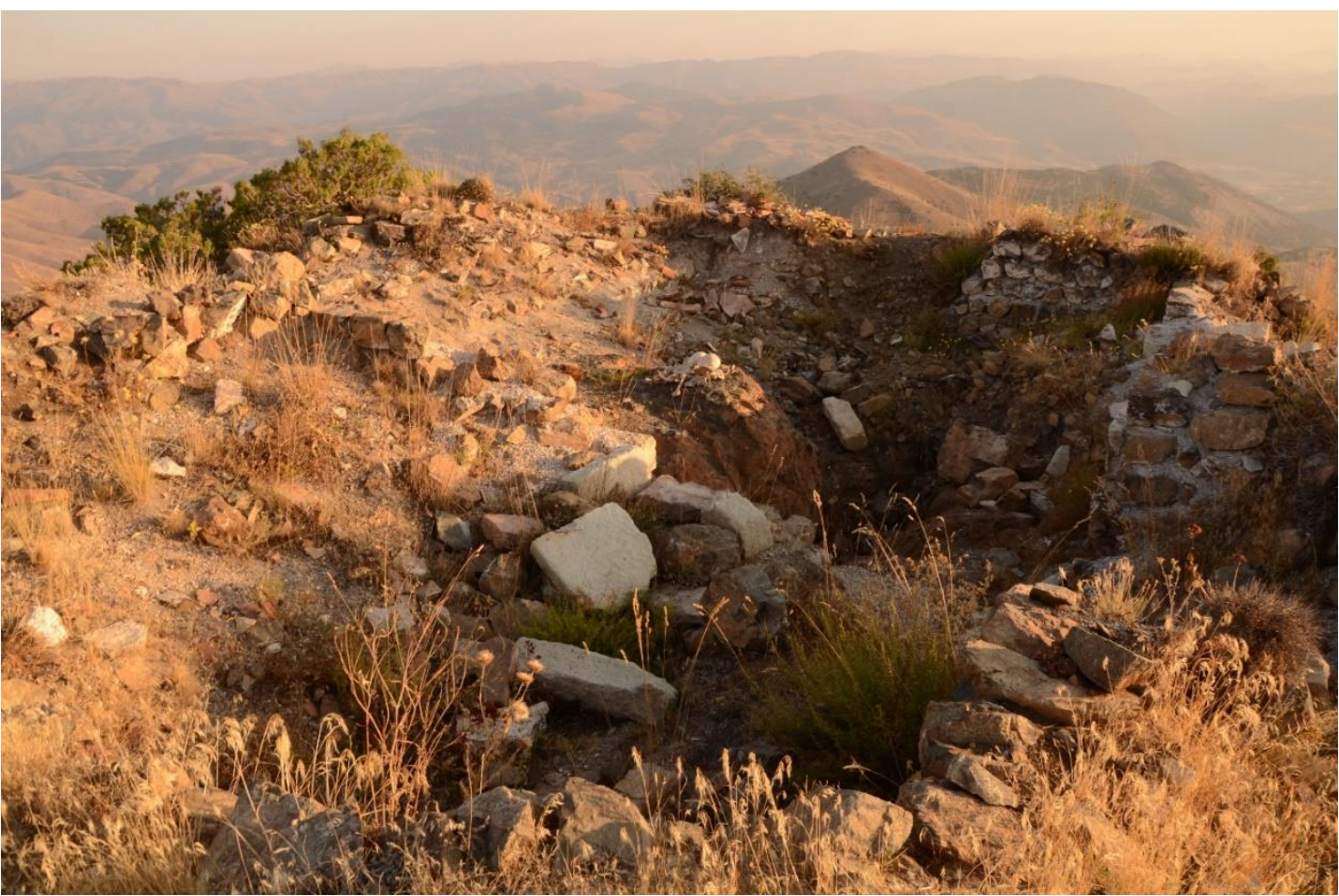


Resim 5: Yazyurdu Köyü, Kale-Gözetleme Kulesi seramik yığıntısı

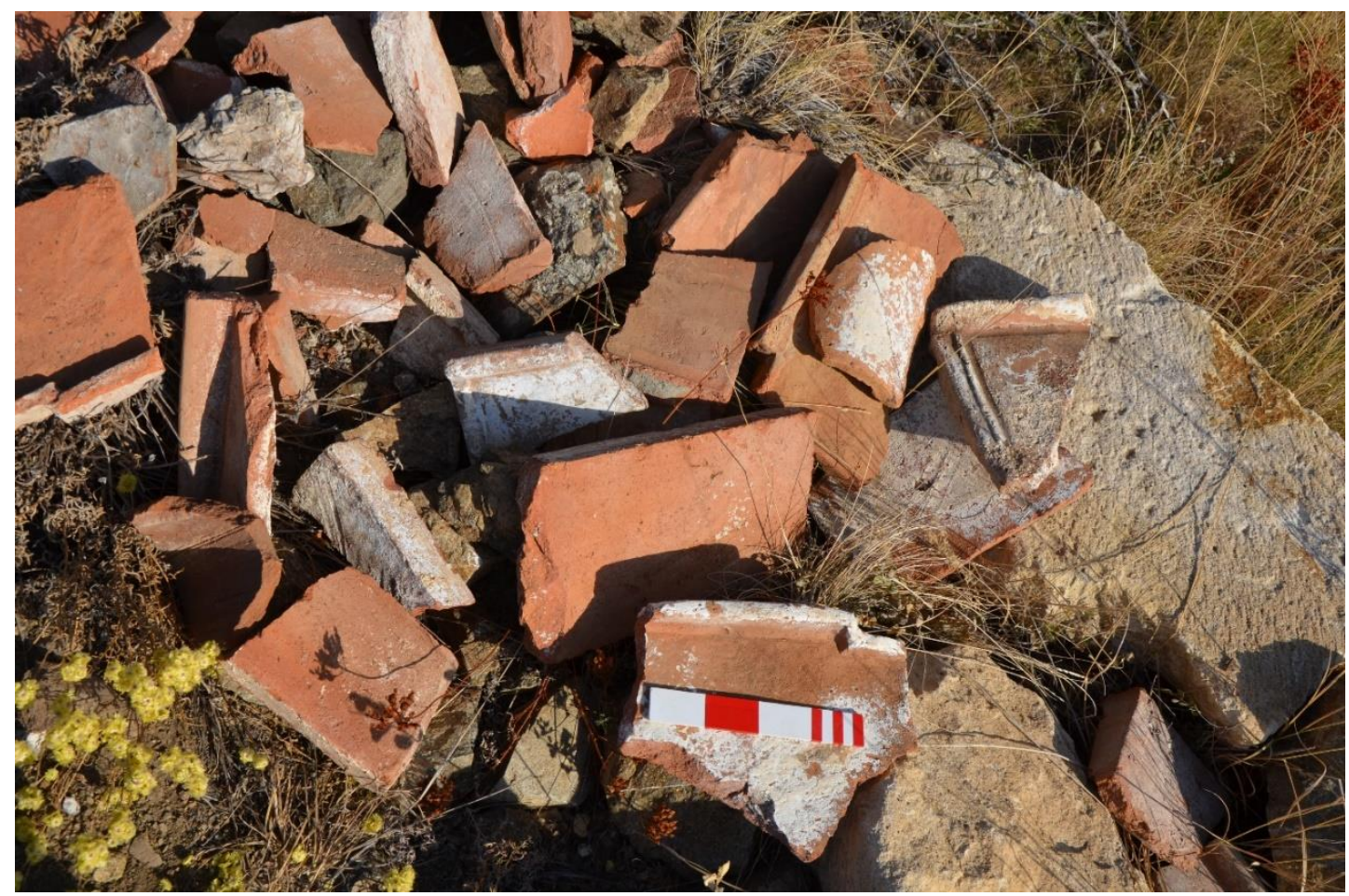

Resim 6: Yeniköy Yerleşim Alanı Seramik Örnekleri, Yeniköy, Bayburt

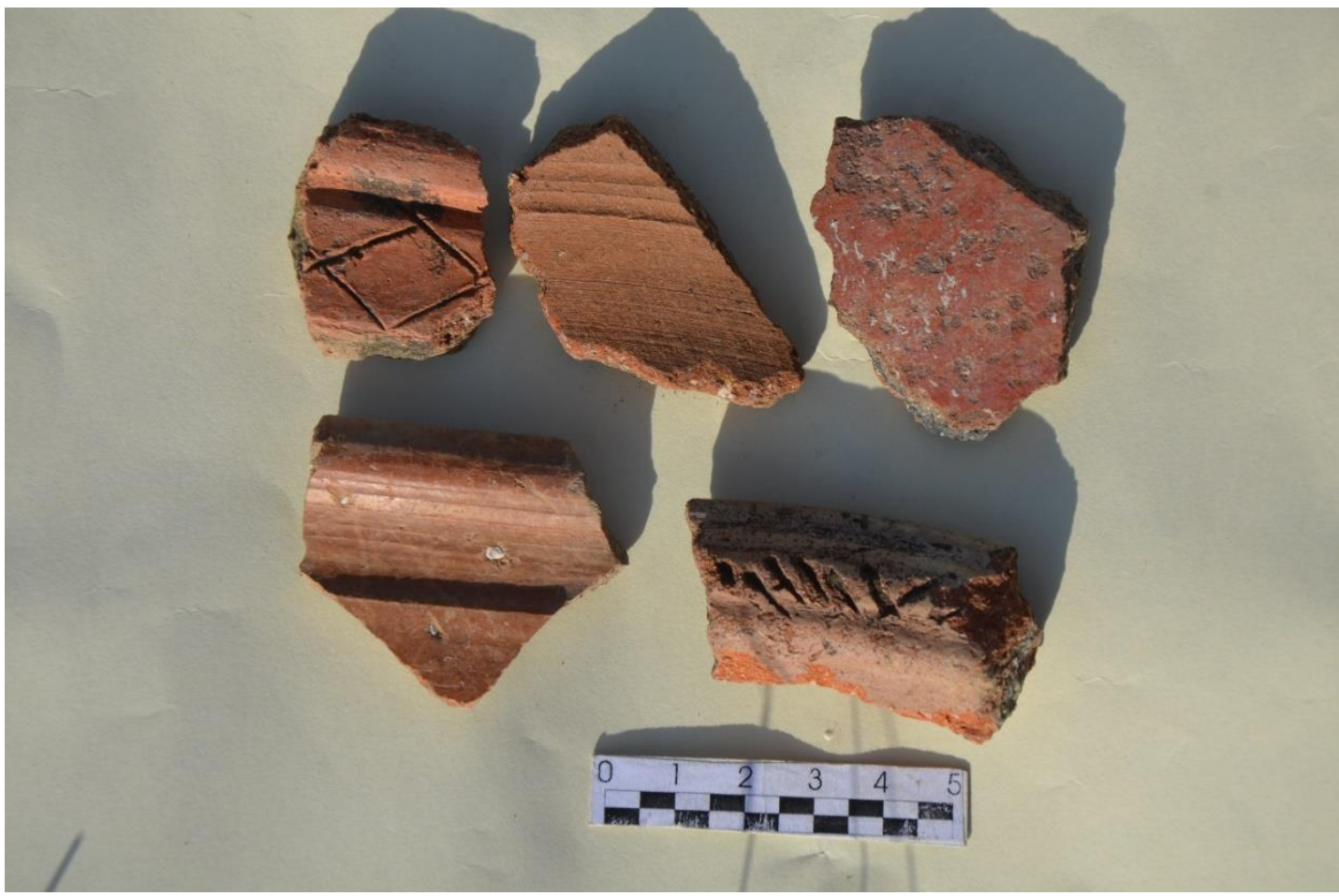


Resim 7: Sınır Tarla Yamaç Yerleşimi Seramiği, Karşıgeçit Köyü, Bayburt

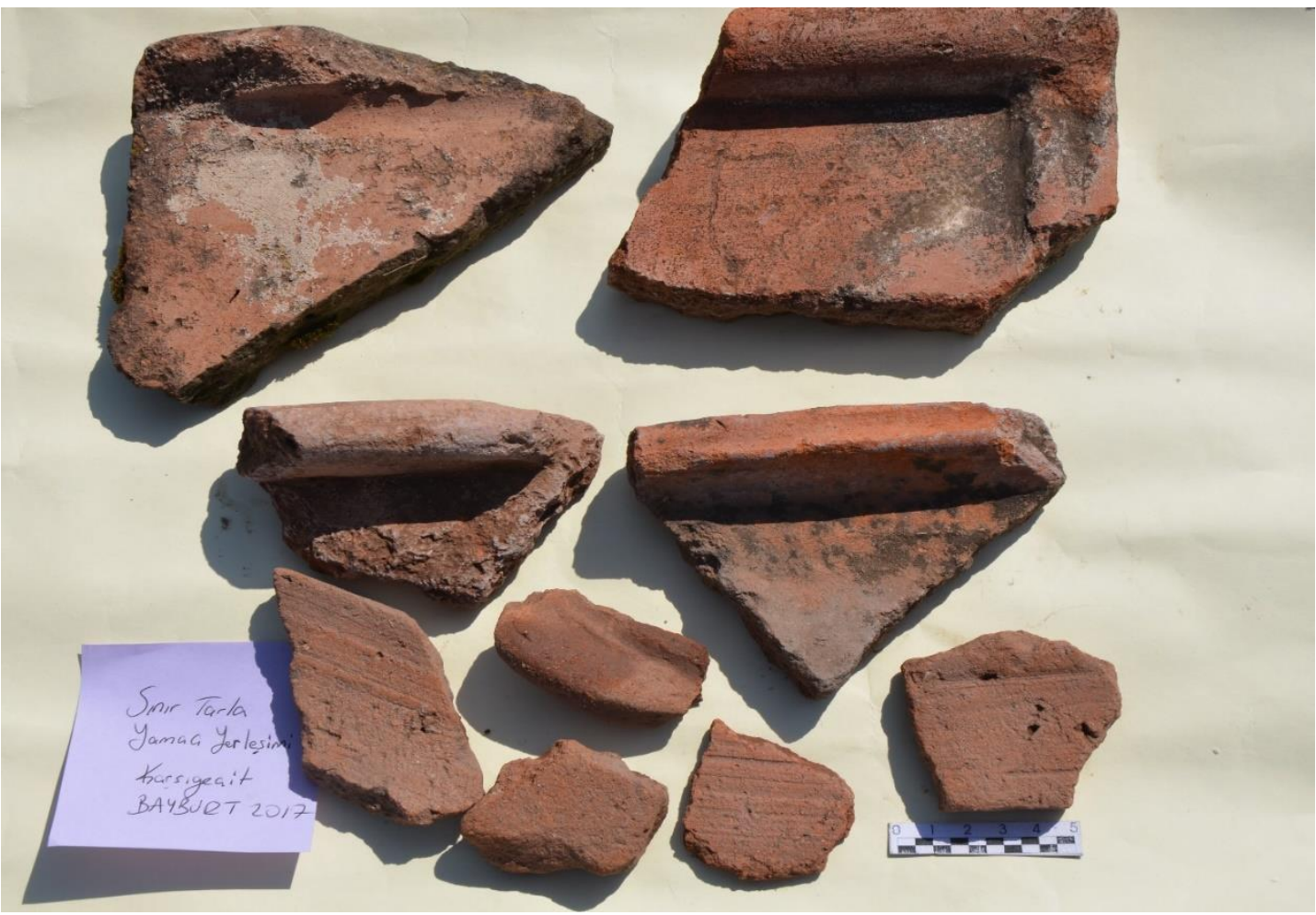

Harita 1: Roma Mithradates Savaşları (Brill's New Pauly Supplement 1, Vol 3).

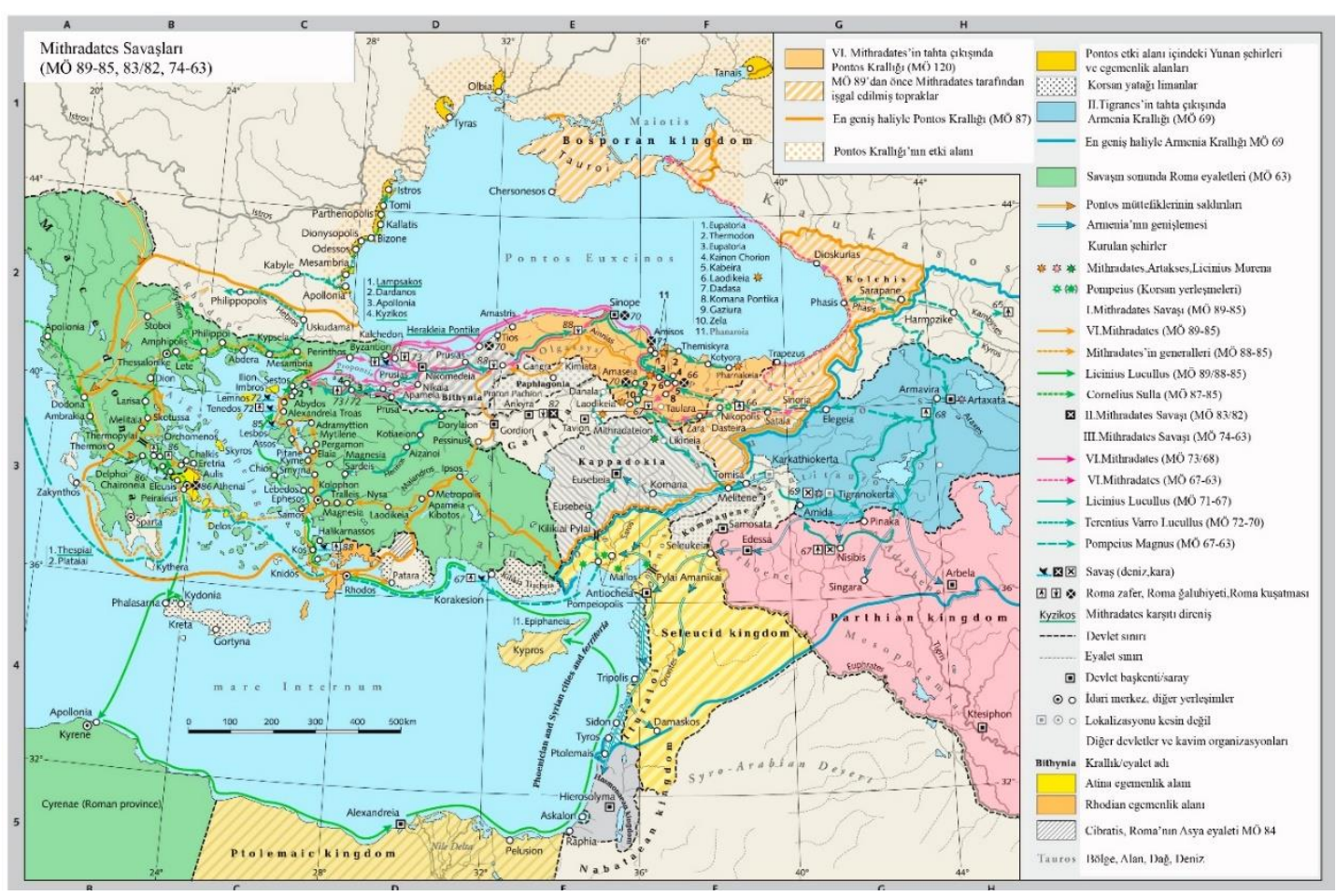


Harita 2: Pompeius'un doğudaki düzenlemeleri (Brill’s New Pauly Supplement 1, Vol 3).

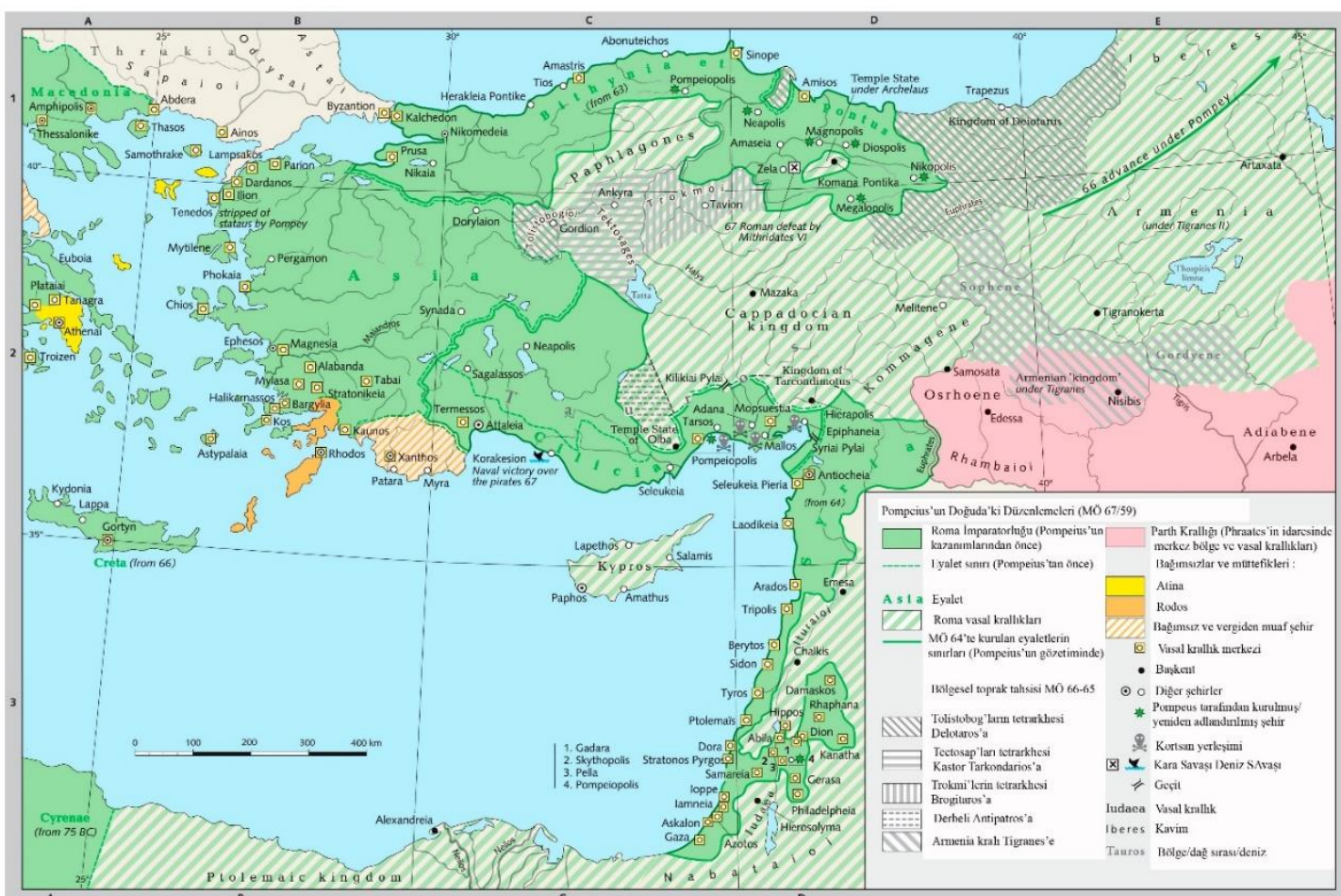

Harita 3: Anadolu'da Roma Eyaletleri (MÖ II. yy. - MS IV. yy). (Brill's New Pauly Supplement 1, Vol 3).

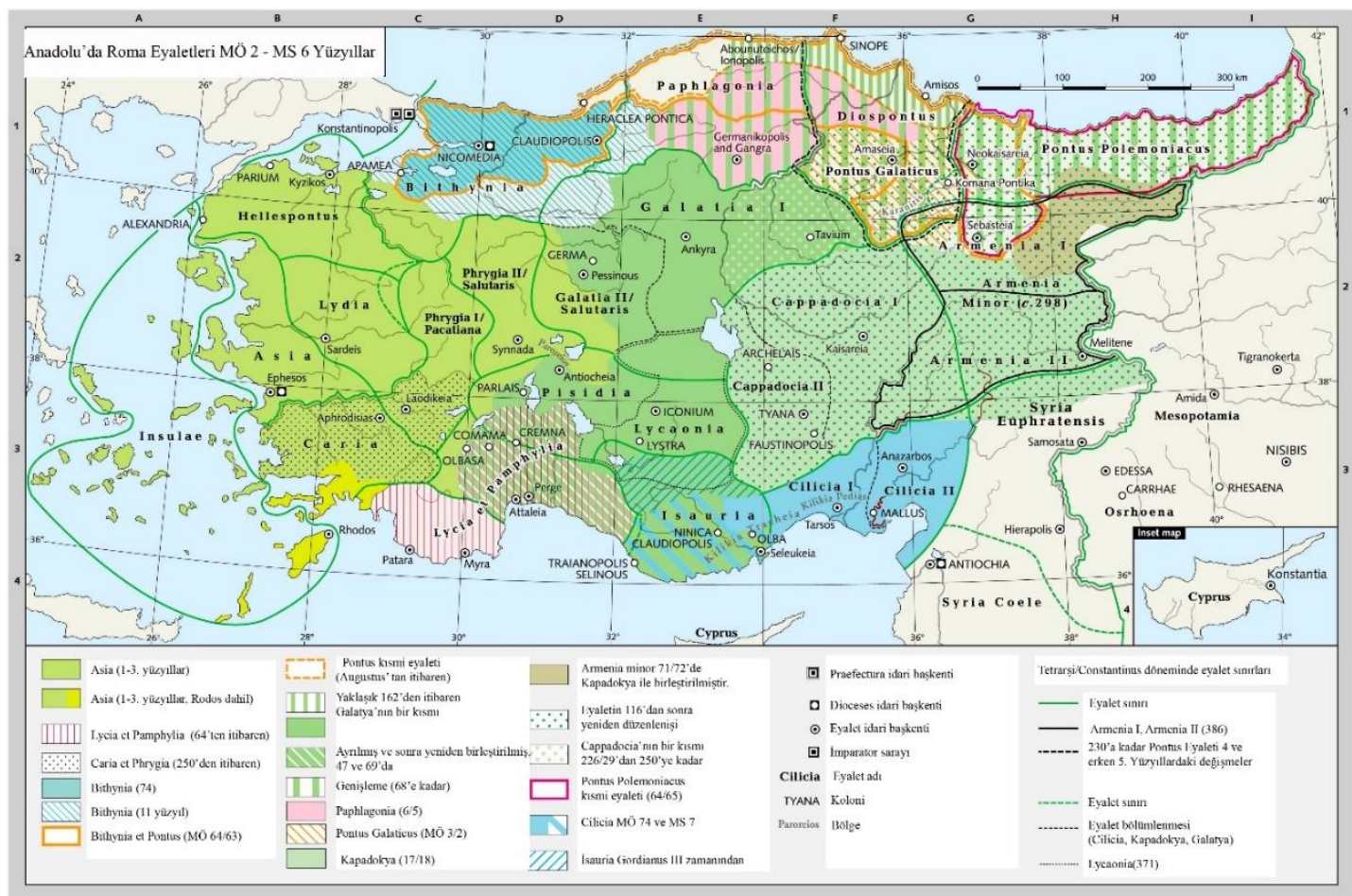

